OAK RIDGE

NATIONAL LABORATORY

ORNL/TM-2005/215

MANAGED BY UT-BATTELLE

FOR THE DEPARTMENT OF ENERGY

\title{
Environmental Survey Report for the ETTP: Environmental Management Waste Management Facility (EMWMF) Haul Road Corridor, Oak Ridge, Tennessee
}
M. J. Peterson
N. R. Giffen
M. G. Ryon
L. R. Pounds
E. L. Ryan, Jr.

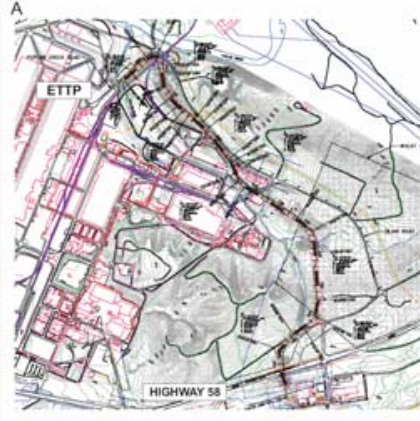

LEGEND

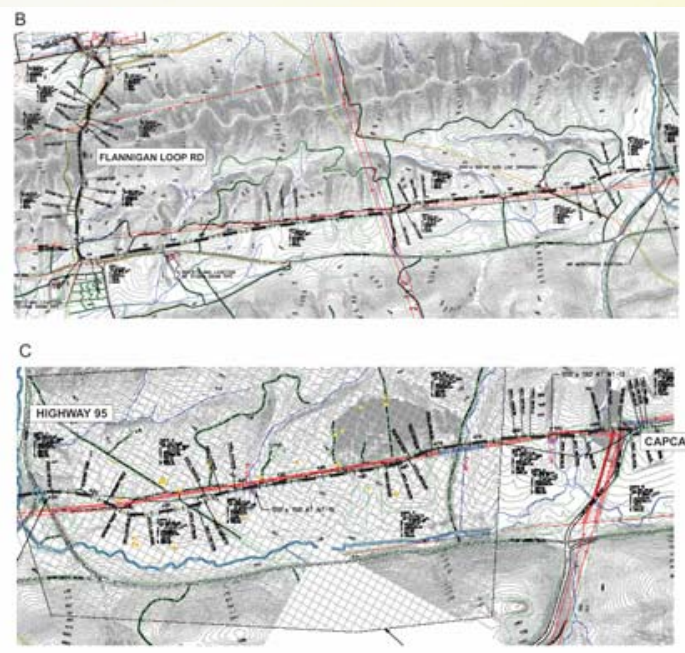

September 2005
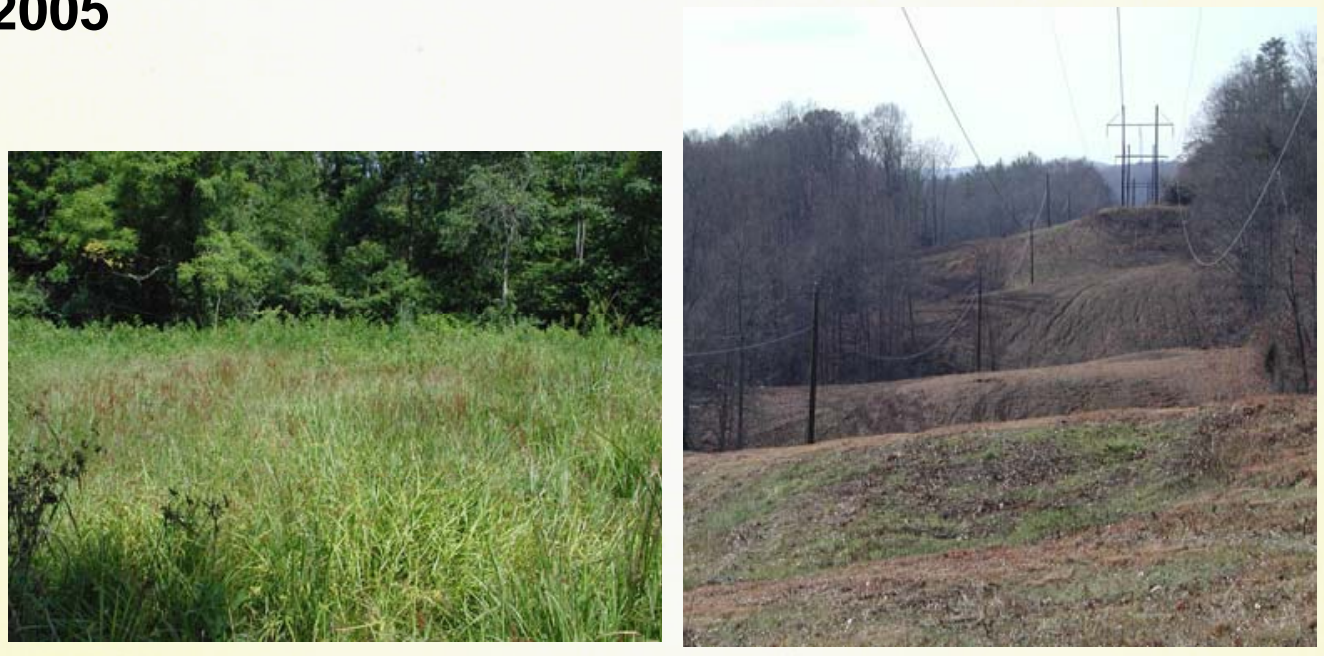


\section{DOCUMENT AVAILABILITY}

Reports produced after January 1, 1996, are generally available free via the U.S. Department of Energy (DOE) Information Bridge.

Web site http://www.osti.gov/bridge

Reports produced before January 1, 1996, may be purchased by members of the public from the following source.

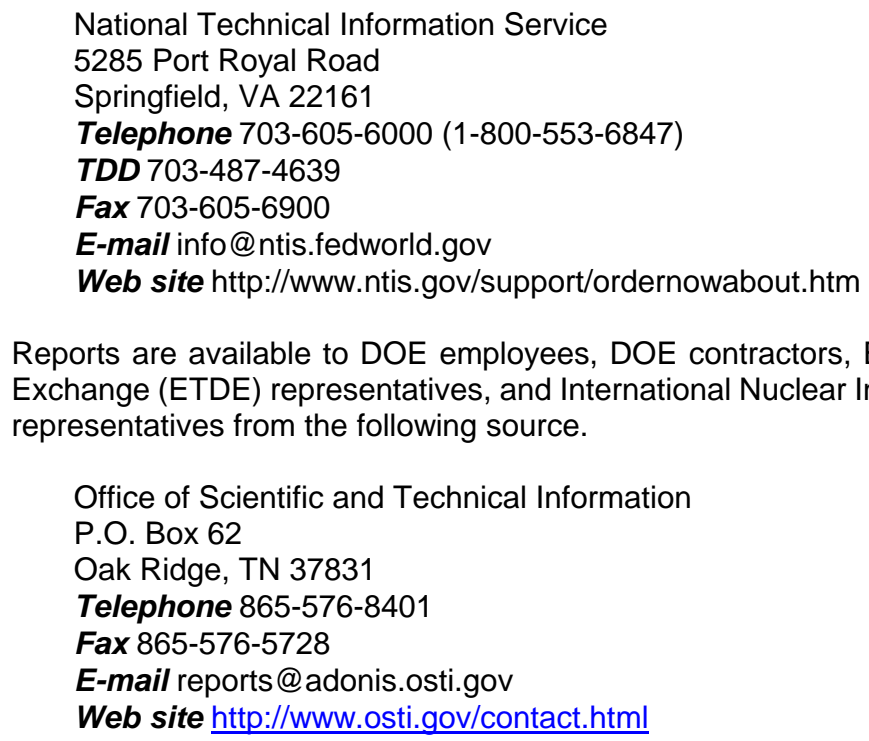
representatives from the following source.

Office of Scientific and Technical Information

P.O. Box 62

Oak Ridge, TN 37831

Telephone 865-576-8401

Fax 865-576-5728

E-mail reports@adonis.osti.gov

Web site http://www.osti.gov/contact.html

Reports are available to DOE employees, DOE contractors, Energy Technology Data Exchange (ETDE) representatives, and International Nuclear Information System (INIS)

This report was prepared as an account of work sponsored by an agency of the United States Government. Neither the United States government nor any agency thereof, nor any of their employees, makes any warranty, express or implied, or assumes any legal liability or responsibility for the accuracy, completeness, or usefulness of any information, apparatus, product, or process disclosed, or represents that its use would not infringe privately owned rights. Reference herein to any specific commercial product, process, or service by trade name, trademark, manufacturer, or otherwise, does not necessarily constitute or imply its endorsement, recommendation, or favoring by the United States Government or any agency thereof. The views and opinions of authors expressed herein do not necessarily state or reflect those of the United States Government or any agency thereof. 


\title{
ENVIRONMENTAL SURVEY REPORT FOR THE ETTP: ENVIRONMENTAL MANAGEMENT WASTE MANAGEMENT FACILITY (EMWMF) HAUL ROAD CORRIDOR OAK RIDGE, TENNESSEE
}

\author{
M. J. Peterson \\ N. R. Giffen \\ M. G. Ryon \\ L. R. Pounds ${ }^{1}$ \\ E. L. Ryan, Jr. ${ }^{2}$
}

Environmental Sciences Division

Oak Ridge National Laboratory

Date Published: September 2005

\section{Prepared for}

Bechtel Jacobs Company LLC 1009 Commerce Park

Oak Ridge, Tennessee 37830

\author{
Prepared by \\ OAK RIDGE NATIONAL LABORATORY \\ P.O. Box 2008 \\ Oak Ridge, Tennessee 37831-6283 \\ managed by \\ UT-Battelle, LLC \\ for the \\ U.S. DEPARTMENT OF ENERGY \\ under contract DE-AC05-00OR22725
}

${ }^{1}$ ORNL Personal Services Contract

${ }^{2}$ ORNL Environmental Protection and Waste Services Division 



\section{CONTENTS}

Page

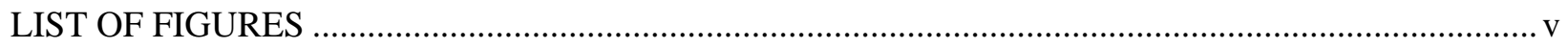

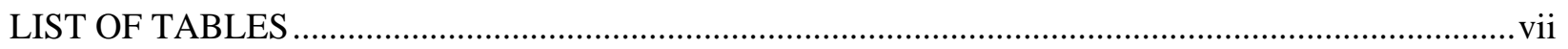

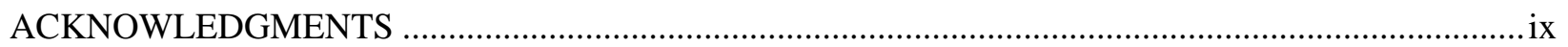

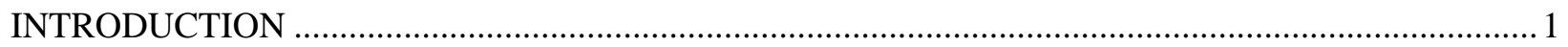

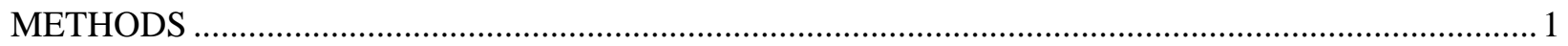

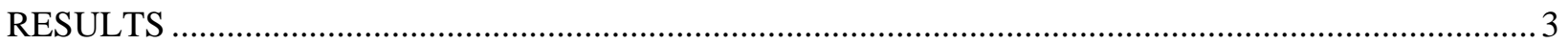

GENERAL DESCRIPTION OF AFFECTED ENVIRONMENT .......................................................... 3

RARE PLANTS AND VEGETATION ASSEMBLAGES ….................................................................. 5

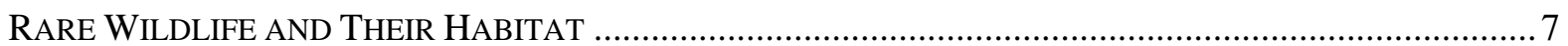

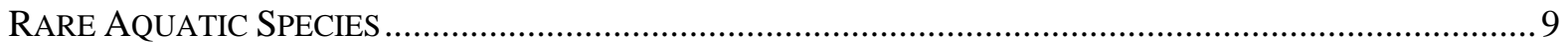

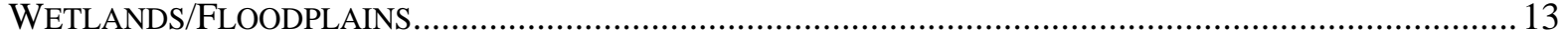

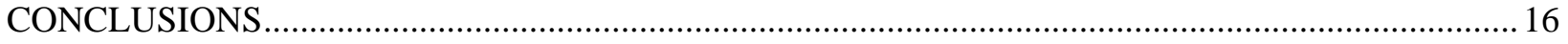

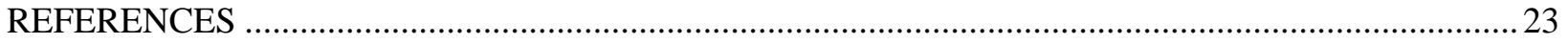

APPENDIX A: RARE PLANT AND WILDLIFE SURVEY ….....................................................

APPENDIX B: THE REPRODUCTIVE BIOLOGY OF THE TENNESSEE DACE .......................... B-1

APPENDIX C: LIST OF WETLAND PLANTS IDENTIFIED ON APRIL 1, 2005 WITHIN

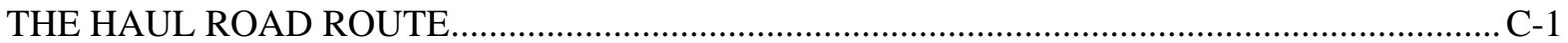





\section{LIST OF FIGURES}

Figure

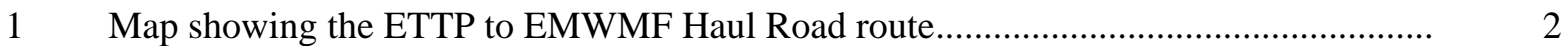

2 Map showing previously-designated Oak Ridge Reservation sensitive resources in the

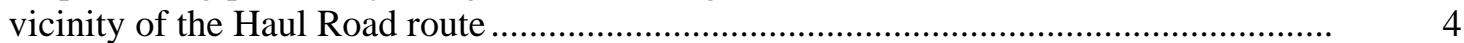

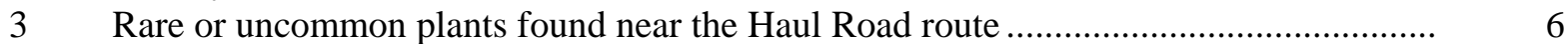

$4 \quad$ Male Tennessee dace from Pinhook Branch, Oak Ridge Reservation in spawning colors. 12

5 Topographic map showing location of 15 wetlands delineated within the ETTP Haul

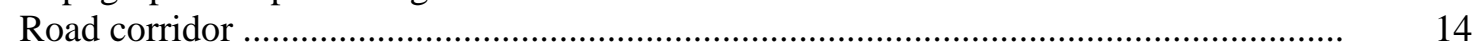

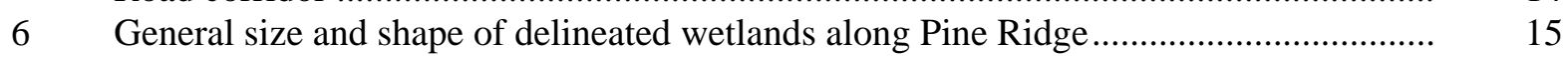

$7 \quad$ Photos of common wetland types encountered along the Haul Road route ....................... 19

8 Contrast between commonly encountered non-wetland soil and wetland soil surveyed within the Haul Road route ..................................................................................... 19 



\section{LIST OF TABLES}

Table

Page

1 Description of general land and habitat types impacted by the Haul Road and the approximate area impacted..

2 Vascular plant species listed by state or federal agencies that are currently known or previously reported from the ORR.

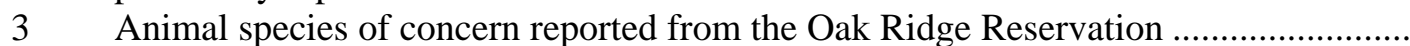
Wildlife species recorded along the proposed Haul Road corridor.................................. Wetland size and type within the Haul Road corridor Routine wetland determination data for forested wetland site near Bear Creek, within the proposed route of the ETTP-EMWMF Haul Road corridor, as determined on March 23, 2005. 



\section{ACKNOWLEDGMENTS}

Many individuals contributed to this document and their input is much appreciated. We thank Bechtel Jacobs Corporation staff for funding the project. Those who contributed to the report include staff from Oak Ridge National Laboratory, U.S. Department of Energy, Bechtel Jacobs Corporation, Jacobs Engineering, Tennessee Department of Environment and Conservation, and Tennessee Wildlife

Resources Agency. We would like to specifically thank the following people for their support in the field and helpful comments on this document: Jimmy Ashworth, Bill Barton, Tom Conrad, Jim Evans, Lindsey Hobson, Charlie Hyer, Linda Houlberg, Robin Manning, Lea Mashburn, Scott Nolter, David Page, Pat Parr and Joe Williams. Lana McDonald provided invaluable work on the production of the report. Sherri Cotter provided support on the figures for this document. Select figures were also provided for the report by Bechtel Jacobs Corporation and/or their subcontract staff. 



\section{ENVIRONMENTAL SURVEY REPORT FOR THE ETTP: ENVIRONMENTAL MANAGEMENT WASTE MANAGEMENT FACILITY (EMWMF) HAUL ROAD CORRIDOR, OAK RIDGE, TENNESSEE}

\section{INTRODUCTION}

This report summarizes the results of environmental surveys conducted within the corridor of a temporary haul road ("Haul Road”) to be constructed from East Tennessee Technology Park (ETTP) to the Environmental Management Waste Management Facility (EMWMF) located just west of the Y-12 National Security Complex (Y-12). Environmental surveys were conducted by natural resource experts at Oak Ridge National Laboratory who routinely assess the significance of various project activities on the Oak Ridge Reservation (ORR). ORNL assistance to the Haul Road Project included environmental assessments necessary to determine the best route for minimizing impacts to sensitive resources such as wetlands or rare plants. Once the final route was chosen, environmental surveys were conducted within the corridor to evaluate the impacts to sensitive resources that could not be avoided.

The final Haul Road route follows established roads and a power-line corridor to the extent possible (Fig. 1). Detailed explanation regarding the purpose of the Haul Road and the regulatory context associated with its construction is provided in at least two major documents and consequently is not presented here: (1) Explanation of Significant Differences for the Record of Decision for the Disposal of Oak Ridge Reservation Comprehensive Environmental Response, Compensation, and Liability Act of 1980 Waste, Oak Ridge, Tennessee (January 2005, DOE/OR/01-2194\&D2), and (2) Environmental Monitoring Plan for The ETTP to EMWMF Haul Road for the Disposal of Oak Ridge Reservation Comprehensive Environmental Response, Compensation, and Liability Act of 1980 Waste, Oak Ridge, Tennessee (April 2005, BJC/OR-2152). The focus of this report is a description of the sensitive resources to be impacted by Haul Road construction. Following a short description of the methods used for the environmental surveys, results and observations are presented in the following subsections:

- General description of the affected environment

- Rare plants and vegetation assemblages

- Rare wildlife and their habitat

- Rare aquatic species

- Wetlands/Floodplains

A summary of project actions taken or planned in order to avoid, minimize, or mitigate the environmental impacts associated with this project are summarized in the conclusion section of this report.

\section{METHODS}

The first sensitive resource surveys for the Haul Road Project were conducted along preliminary routes in July 2004. Additional walk-downs were conducted in the fall and winter of that year, but surveys of the final route were not performed until January 2005 for the ETTP to Flannigan Loop section, and March-April 2005 for the Flannigan Loop to CAPCA Haul Road section. In general, walk-down surveys were qualitative in nature, with past survey data from the area obtained for the ORR's National Environmental Research Park (NERP) studies and staff knowledge serving as a basis for survey evaluation. 


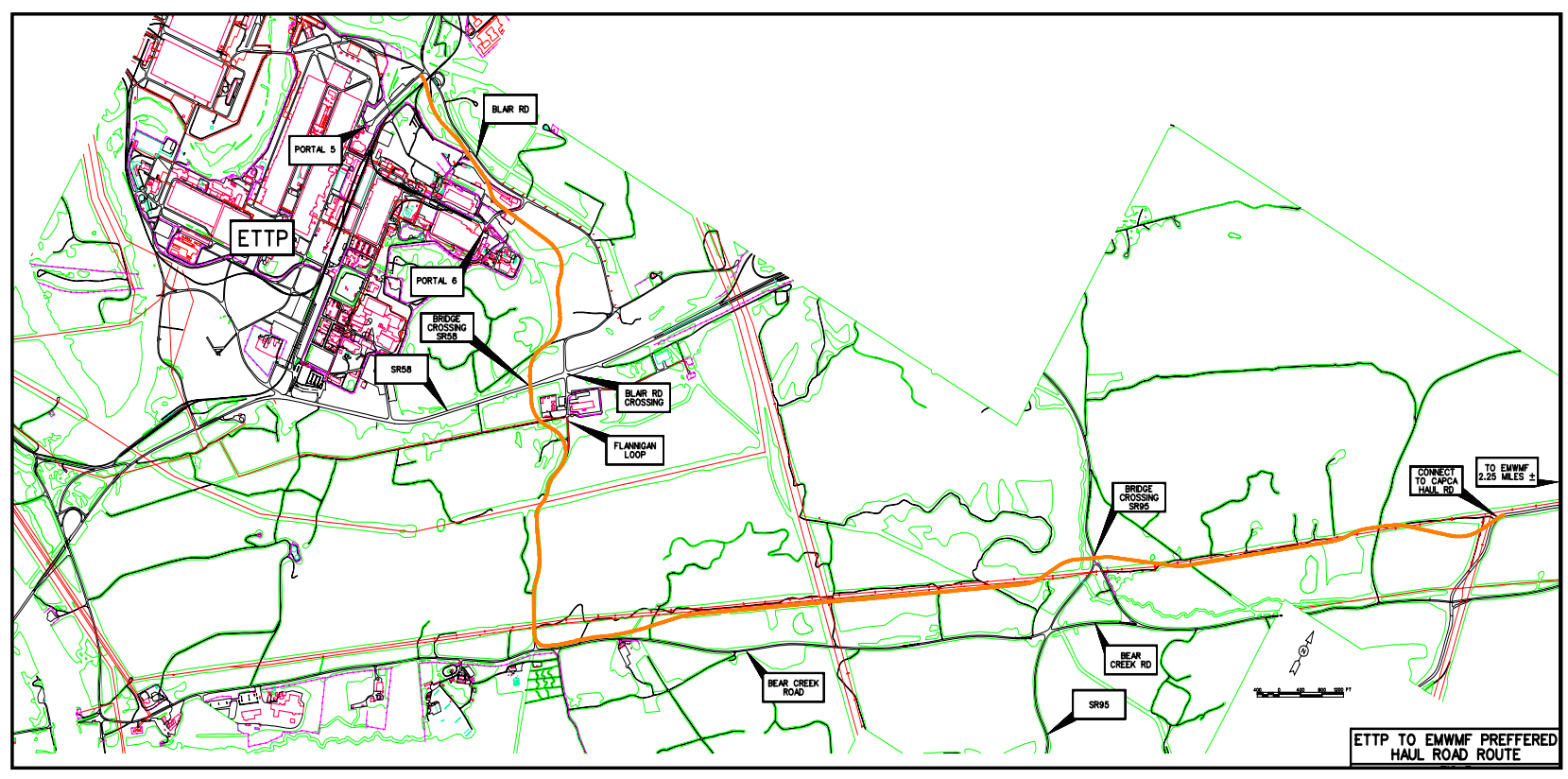

Fig. 1. Map showing the ETTP to EMWMF Haul Road route.

Route highlighted in light orange color. Map provided by Jacobs Engineering.

Of particular interest on these surveys were the presence (or evidence) of any state or federally listed species (both terrestrial and aquatic), as well as any significant or unique habitat that could potentially be impacted by construction activities.

Wetlands are considered of high ecological value; consequently, destruction or loss of wetlands, as well as major disturbance such as dredging or filling of wetlands, is regulated by both federal and state agencies. Wetlands within the Haul Road corridor were determined and delineated per Army Corps of Engineers' wetland delineation protocols (ACOE 1987). To be considered a jurisdictional wetland, a site must meet the necessary hydrology, soils, and wetland-vegetation criteria. For each wetland plant community type, the dominant plant species and their abundance were noted, and bore holes were dug to evaluate and characterize the soils and hydrology of the site. Wetland locations were mapped with a GARMIN 76S Mapping handheld GPS unit and accompanying software.

The wetland vegetation criterion is met if more than $50 \%$ of the dominant species within each stratum (trees, shrubs, woody vines, herbs) are hydrophytic. To make this determination, species are assigned an indicator status based on the U.S. Fish and Wildlife Service (1997) National List of Plant Species that Occur in Wetlands: 1988 National Summary. The indicator species status codes are: obligate wetland (OBL), facultative wetland (FACW), facultative (FAC), facultative upland (FACU), and upland (UPL). A plus (+) or minus (-) sign following the indicator code denotes a tendency towards the wetter $(+)$ or drier (-) end of the scale. For classifying an area as hydrophytic, the dominant plant species in each stratum must have the following vegetation species codes: OBL, FACW+, FACW, FACW-, FAC+, or FAC. Indicator definitions, as defined by the U.S. Fish and Wildlife Service, are:

Obligate Wetland (OBL). Occur almost always (estimated probability $>99 \%$ ) under natural conditions in wetlands. 
Facultative Wetland (FACW). Usually occur in wetlands (estimated probability $67 \%-99 \%$ ), but occasionally found in non-wetlands.

Facultative (FAC). Equally likely to occur in wetlands or non-wetlands (estimated probability 34\%-66\%).

Facultative Upland (FACU). Usually occur in non-wetlands (estimated probability 67\%-99\%), but occasionally found in wetlands (estimated probability 1\%-33\%).

Obligate Upland (UPL). Occur in wetlands in another region, but occur almost always (estimated probability $>99 \%$ ) under natural conditions in non-wetlands.

Soil samples were extracted at multiple locations using a post-hole shovel to characterize the wetland sites and to assist in determining appropriate wetland boundaries. Soil samples were extracted to a depth of 24-36 inches if possible, which was deep enough to evaluate the A and much of the B horizons. In most cases, a shallower hole was dug because the soil was too hard to penetrate or surface water was present. The soil sample was examined for soil color and texture and reported per Munsell Company (1994) designations. The presence of mottles, manganese concretions, high organic content, and other indicators of hydric soil status was also examined.

The sites were examined for primary and secondary indicators of wetland hydrology. The presence and depth of surface water, as well as the soil saturation and depth to free water in the soilboring hole was evaluated. The presence of watermarks, drift lines, oxidized root channels, water-stained leaves, and other indicators of wetland hydrology were also noted.

\section{RESULTS}

\section{General Description of Affected Environment}

The Haul Road route traverses a wide variety of habitats, including areas previously designated as sensitive by The Nature Conservancy and other researchers (Fig. 2). However, a large percentage of the area to be impacted by the Haul Road is composed of common, non-sensitive habitats. The approximate acreage of land and habitat types impacted by the Haul Road is provided in Table 1.

Over three quarters of the area impacted by the Haul Road consists of disturbed or common habitat types. Over half of those non-sensitive areas are comprised of highly developed areas like roads, mowed grasses, and power-line areas that are routinely roller-chopped or mowed to prevent growth of woody trees and shrubs. The other non-sensitive habitat types are in various early successional stages, and include habitats such as old fields, woody thickets, forest edge communities, and planted loblolly pine areas (including those impacted by pine beetle infestations). Although these land and habitat types are common in east Tennessee, they do provide benefits to common wildlife species that utilize grassland and edge forest habitats (see more information in the following wildlife section).

More regionally sensitive habitats found within the Haul Road route include a variety of forest types, including approximately 6.4 acres of bottomland forest and 4 acres of mixed or mixed-pine deciduous forest. The loss of forest habitat is a concern for wildlife populations in the area, specifically neotropical migratory songbirds. Consequently, Haul Road redesigns were conducted to minimize this 


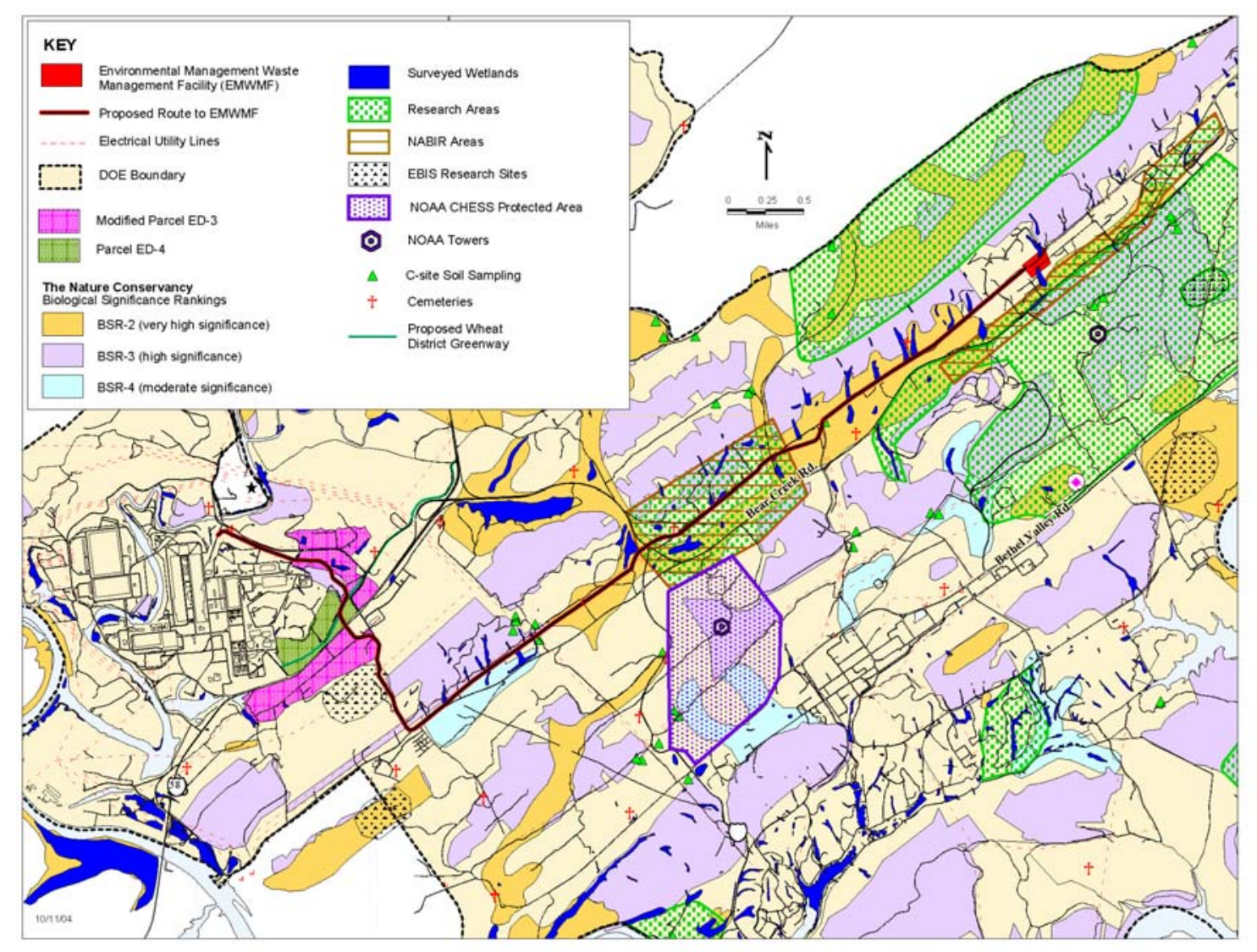

Fig. 2. Map showing previously-designated Oak Ridge Reservation sensitive resources in the vicinity of the Haul Road route. Base map by Sherri Cotter.

impact to the maximum extent possible. In particular, modifications were made in the haul road corridor route to avoid clearing through the middle of large contiguous areas of forest, which could have resulted in significant forest fragmentation.

Wetlands provide important ecological functions and, as a result, are considered highly valuable habitat by natural resource managers. Both forested and marsh wetlands were delineated for this assessment, comprising 1.35 acres of jurisdictional wetland habitat. Forested wetlands closely bordered the streams and headwater areas near springs and seeps. Two thirds of the total forested wetlands were found adjacent to Bear Creek. Approximately a half acre of wetlands, divided into multiple small areas near headwater streams, were marsh wetlands below power-lines.

The western road approach and bridge crossing of Bear Creek is undoubtedly the most sensitive area to be impacted by the Haul Road. This floodplain area, consisting of large continuous forested wetlands and bottomland woods, is adjacent to the Rein Orchid Swamp, a registered State Natural Area. The forested wetlands associated with the Bear Creek bottoms are of high natural quality, with extensive seepage flow and relatively large areas of bulbous-based trees growing in standing water. The eastern side of Bear Creek within the Haul Road route included a large cane break, which is a vegetation community type designated by The Nature Conservancy as globally rare. Bear Creek itself contains the rare Tennessee dace and other pollution-intolerant fish species. As a result of the presence of this rare species and 
Table 1. Description of general land and habitat types impacted by the Haul Road and the approximate area impacted (by acreage and percentage of total)

\section{General Land or Habitat Type} Approximate Acreage
Impacted
Approximate

Percentage of Total

Area Impacted

\section{Regionally Common}

Developed Area (e.g., roads and closely-

mowed areas)

10.1

10.5

6.7

.6

3.6

7.2

3.0

41.7

2.1

1.9

6.4

0.5

0.8

11.7
19.0

19.7

12.6

1.1

6.7

13.5

5.6

78.2

\section{More Regionally Sensitive}

Forest - Mixed Deciduous

Forest - Mixed Pine/Deciduous

Forest - Bottomland

Wetland - Marsh

Wetland - Forested

Subtotal

TOTAL

53.4 acres

3.9

3.5

12.0

0.9

1.5

21.8

concerns regarding potential negative impacts of the original bridge designs, a bridge was designed to span Bear Creek in place of a planned culvert. This redesign specifically addressed concerns regarding stream sediment disturbance and potential impacts on Tennessee dace migration. In addition, the road approach to the crossing of Bear Creek was relocated in order to take advantage of the presence of slightly higher ground. As a result, disturbance of more extensive areas of wetlands to both the north and south was avoided.

\section{Rare Plants and Vegetation Assemblages}

The natural vegetation of the ORR is the most significant area of preserved natural vegetation in the Ridge and Valley Physiographic Province in Tennessee (Mann et al 1995). The Haul Road route passes through some of this natural vegetation. Much of the Haul Road route is in a mowed power-line right-of-way. Although mowed areas often are not considered to be natural vegetation, some areas of the mowed right-of-way within the Haul Road route function much like natural prairie vegetation. This prairie-like plant community has a high diversity of native plant species. This is due to its annual rather than more frequent mowing and lack of dominating exotic plant species. A few of the uncommon wildflowers found on the right-of-way are sessile blazing star, lesser basal-leaved rosin-weed and purple fringeless orchid. Canada lily, a state protected species, is present within the right-of-way to the east of the Haul Road route (Fig. 3). 

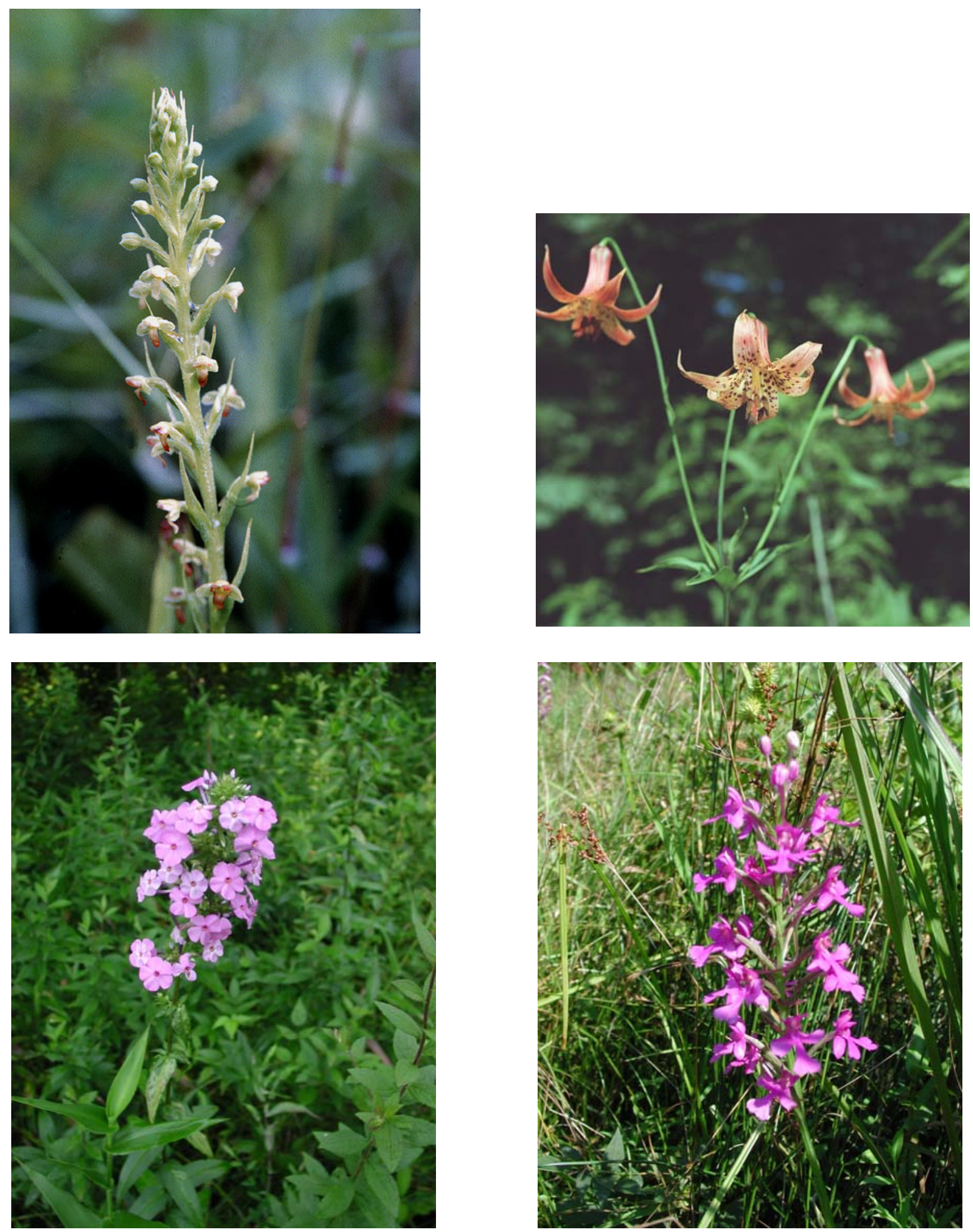

Fig. 3. Rare or uncommon plants found near the Haul Road route. Rare plant species encountered were avoided by making adjustments to the road alignment. Clockwise from top-left: Tuberculed reinorchid (Plantanthera flava var. herbiola), Canada lily (Lilium canadense), purple fringeless orchid (Platanthera peramoena) and Wild Sweet William (Phlox maculata). 
The mixed and mixed-pine deciduous forests within the Haul Road route are dominated by various species of oaks, red maple, tulip poplar and sweetgum. Although individual species within these communities are not rare in Tennessee, the value of these communities is in its lack of fragmentation relative to the agricultural land and urban development that surrounds the ORR. The relatively rare Ridge and Valley Beech-Mountain Laurel Community occurs nearby but was avoided by the final road alignment.

The forested wetlands and bottomland adjacent to Bear Creek was supported by extensive seepage flow that has resulted in swamp-like conditions in many areas. This plant community type is of high natural quality and is relatively rare in the region, with the Bear Creek community being an unusually large example. A noteworthy plant assemblage within the riparian area of Bear Creek is a large cane break, a community type considered globally rare by the Nature Conservancy.

Although approximately 12 acres within the Haul Road route could be considered to be in a natural state, no state or federally listed plant species have been previously identified within the boundaries of the final road alignment, and none were found during the present surveys. Twenty two species of plants found on the Oak Ridge Reservation are listed for protection by the state of Tennessee (Table 2). Based on the known locations of these species on the ORR, only two of these 22 listed species could reasonably be expected within the Haul Road route. One of these two, Canada lily (Lilium canadense), was not found near the route though it does occur in the same power-line right-of-way to the east. Tuberculed rein-orchid (Plantanthera flava var. herbiola), which has state threatened status, is found at five locations near the Haul Road route. Two of these locations were newly discovered during the Haul Road botanical surveys, but all were avoided by the present alignment. Tuberculed rein-orchid is a northern species at the very southern edge of its entire range on the ORR. It is found on the ORR mostly in forested wetlands.

\section{Rare Wildlife and Their Habitat}

Wildlife resource surveys were conducted along the corridor between July 2004 and March 2005. A detailed description of habitats surrounding each survey marker is provided in Appendix A. The majority of the proposed haul road corridor traverses developed, mowed, old field, and edge habitat where common wildlife species are found. The majority of the bird species recorded along the corridor were typical edge and old field species. These included Carolina wren (Thryothorus ludovicianus), common yellowthroat (Geothlypis trichas), eastern towhee (Pipilo erythrophthalmus), field sparrow (Spizella pusilla), northern cardinal (Cardinalis cardinalis) and indigo bunting (Passerina cyanea).

The fragmentation of interior forest was a major initial concern with the project. Initial generation of options included an alignment through forested areas that could have potentially impacted forest interior neotropical migrant birds. Neotropical migrant bird species of note during early haul road route surveys included yellow-billed cuckoo (Coccyzus americanus), acadian flycatcher (Empidonax virescens) and red-eyed vireo (Vireo olivaceus). A major concern for ORR land management is that repeated road cuts over a period of time will slice forested areas into such small blocks that they become no longer viable for such species. An additional concern regarding road cuts is that they provide routes for predators that impact these forest interior birds. Although route alignments through forested areas were efficient from an engineering standpoint, modifications were made to protect this important habitat.

The Haul Road corridor crosses a variety of wetlands habitat. Potential impacts to amphibian species were a concern in these areas. Many of the areas to be traversed contain habitat for spring breeding frog populations. Southeastern chorus frogs (Pseudacris feriarum) were prevalent in these areas. The Haul Road alignment was adjusted to avoid the most sensitive areas of wetlands habitat. 
Table 2. Vascular plant species listed by state or federal agencies that are currently known or previously reported from the ORR

\begin{tabular}{|c|c|c|c|}
\hline Species & Common Name & Habitat on ORR & $\begin{array}{l}\text { Status } \\
\text { Code }^{\mathrm{a}}\end{array}$ \\
\hline Aureolaria patula & Spreading false-foxglove & River bluff & $\mathrm{C} 2, \mathrm{~T}$ \\
\hline Carex gravida & Heavy sedge & Varied & S \\
\hline Carex oxylepis var. pubescens ${ }^{b}$ & Hairy sharp-scaled sedge & Shaded wetlands & $\mathrm{S}$ \\
\hline Cimicifuga rubifolia & Appalachian bugbane & River slope & $\mathrm{C} 2, \mathrm{~T}$ \\
\hline Cypripedium acaule & Pink lady’s-slipper & Dry to rich woods & $\mathrm{E}, \mathrm{CE}$ \\
\hline Delphinium exaltatum & Tall larkspur & Barrens and woods & $\mathrm{C} 2, \mathrm{E}$ \\
\hline Diervilla lonicera & Northern bush-honeysuckle & River bluff & $\mathrm{T}$ \\
\hline Draba ramosissima & Branching whitlow-grass & Limestone cliff & $\mathrm{S}$ \\
\hline Elodea nuttallii & Nuttall waterweed & Pond, embayment & $\mathrm{S}$ \\
\hline Fothergilla major & Mountain witch-alder & Woods & $\mathrm{T}$ \\
\hline Hydrastis canadensis & Golden seal & Rich woods & S, CE \\
\hline Juglans cinerea & Butternut & Slope near stream & $\mathrm{C} 2, \mathrm{~T}$ \\
\hline Juncus brachycephalus & Small-head rush & Open wetland & $\mathrm{S}$ \\
\hline Lilium canadense & Canada lily & Moist woods & $\mathrm{T}$ \\
\hline Lilium michiganense $e^{c}$ & Michigan lily & Moist woods & $\mathrm{T}$ \\
\hline Liparis loeselii & Fen orchid & Forested wetland & $\mathrm{E}$ \\
\hline Panax quinquifolius & Ginseng & Rich woods & S, CE \\
\hline Platanthera flava var. herbiola & Tuberculed rein-orchid & Forested wetland & $\mathrm{T}$ \\
\hline Populus grandidentata ${ }^{d}$ & Large-tooth aspen & Dry, woodlands & S \\
\hline Ruellia purshiana & Pursh's wild-petunia & Dry, open woods & $\mathrm{S}$ \\
\hline Scirpus fluviatilis & River bulrush & Wetland & S \\
\hline Spiranthes lucida & Shining ladies-tresses & Boggy wetland & $\mathrm{T}$ \\
\hline Thuja occidentalis & Northern white cedar & Rocky river bluffs & S \\
\hline Viola tripartita var tripartita & Three-parted violet & Rocky woods & $\mathrm{S}$ \\
\hline
\end{tabular}

${ }^{\mathrm{a}}$ Status codes:

C2 = Special concern, under review for federal listing; listed under the formerly used C2 candidate designation. More information needed to determine status.

$\mathrm{E}=$ Endangered in Tennessee.

$\mathrm{T}=$ Threatened in Tennessee.

$\mathrm{S}=$ Special concern in Tennessee.

$\mathrm{CE}=$ Status due to commercial exploitation.

${ }^{\mathrm{b}}$ Carex oxylepis var. pubescens has not been observed during recent surveys.

${ }^{\mathrm{c}}$ Lilium michiganense is believed to have been extirpated from the ORR by the impoundment at Melton Hill.

${ }^{\mathrm{d}}$ Populus grandidentata was reported in two ORR locations in 2003. One of the reports was confirmed, but the tree died during the year. In 2004 additional trees were found in the vicinity of the dead tree. 
Historical surveys of the area in the vicinity of the Haul Road corridor recorded no threatened or endangered animal species, or potential high quality habitat for these species. Threatened, endangered, and special concern species previously documented on the ORR are listed in Table 3.

There is a general concern on the Oak Ridge Reservation for the potential presence of the federally endangered Indiana bat (Myotis sodalis). (Note: The only record of the Indiana bat on the Oak Ridge Reservation is from a single specimen in the 1950s. No maternity roosts have ever been located on the Oak Ridge Reservation.) Indiana bats will use larger trees with exfoliating bark as roost sites starting around mid-May. The bats remain at these roosts until early August or mid September (Harvey et al. 1999). The majority of roosts used by this bat species are under the exfoliating bark of dead or dying trees (Callahan et al. 1997, Gardner et al. 1991, Kurta et al. 1996, U.S. Fish and Wildlife Service 1999). Recent studies de-emphasize the importance of tree species or habitat type, while emphasizing the importance of structural characteristics of roost trees. One recent study documents the common use of conifers by Indiana bat maternity colonies (Britzke et al. 2003). Potential habitat along the proposed haul road corridor is characterized mainly by dead pines resulting from a recent pine beetle infestation.

In order to avoid disturbance of potentially roosting Indiana bats, this project followed the guideline established by the U.S. Fish and Wildlife Service by removing all potential roost trees along the road corridor by March 31 (Letter from Lee A. Barclay to James Elmore - October 13, 2004). Spot clearing of small parcels outside the Haul Road corridor, however, may be required as construction progresses. For example, trees may need to be cleared from construction lay down areas and wetland mitigation sites. Areas to be cleared will be assessed for Indiana bat habitat potential and managed appropriately (e.g., use of mist netting). Also, dead trees at the immediate periphery of the cleared area that pose a safety hazard will need to be removed.

A complete list of wildlife species identified during the present surveys by sight, song call and/or sign along the Haul Road route is presented in Table 4. Two species of birds were encountered that could be considered regionally sensitive. The yellow-bellied sapsucker (Sphyrapicus varius) is listed by the state of Tennessee as a species in need of management, and is a fairly common winter visitor to the ORR. The field sparrow is listed by Partners in Flight as a species in need of conservation in the southern ridge and valley, and is a common nester on the ORR.

\section{Rare Aquatic Species}

The Haul Road route crosses numerous streams, the largest being Bear Creek, which is a moderately sized ( $2^{\text {nd }}$ to $3^{\text {rd }}$ order) stream over the majority of its length. Smaller streams that are crossed by the route, but that contain significant populations of fish, include Mitchell Branch (near ETTP), a western tributary of Bear Creek, and NT-13 (North Tributary), NT-14, and NT-15. The Haul Road follows the southern side of Pine Ridge where it crosses a number of other springs, seeps, and very small tributary streams that flow to either Bear Creek or Grassy Creek.

The fish communities of Mitchell Branch, Grassy Creek, and Bear Creek have been monitored by ORNL's Biological Monitoring and Abatement Program (BMAP). The Mitchell Branch and Grassy Creek watersheds contain fish assemblages that are typical of streams with moderate impact, probably from industrial or urban discharges or poor habitat. The biological communities in the Bear Creek watershed are also impacted by prior waste disposal practices in its headwaters and current land uses (Southworth et al. 1992; Hinzman 1996). The Bear Creek watershed, however, does support one rare fish species, the Tennessee dace (Phoxinus tennesseensis). The Tennessee dace is a species deemed in need of 
Table 3. Animal species of concern reported from the Oak Ridge Reservation. ${ }^{\text {a }}$ Some species (e.g., anhinga) have been seen only once or a few times; others (e.g., sharp-shinned hawk, southeastern shrew) are comparatively common and widespread on the reservation.

\begin{tabular}{|c|c|c|c|c|}
\hline \multirow{2}{*}{ Scientific Name } & \multirow{2}{*}{ Common Name } & \multicolumn{3}{|c|}{ Status $^{b}$} \\
\hline & & Federal & State & $\mathbf{P I F}^{\mathrm{c}}$ \\
\hline \multicolumn{5}{|c|}{ FISH } \\
\hline Phoxinus tennesseensis & Tennessee dace & & NM & \\
\hline Hemidactylium scutatum & $\begin{array}{l}\text { AMPHIBIANS AND REPTILES } \\
\text { four-toed salamander }\end{array}$ & & NM & \\
\hline \multicolumn{5}{|c|}{ BIRDS } \\
\hline Accipiter striatus & sharp-shinned hawk & & NM & \\
\hline Anhinga anhinga & anhinga & & NM & \\
\hline Caprimulgus carolinensis & chuck-will's-widow & & & $\mathrm{C}$ \\
\hline Ardea alba & great egret & & NM & \\
\hline Circus cyaneus & northern harrier & & NM & \\
\hline Contopus cooperi & olive-sided flycatcher & & NM & \\
\hline Dendroica caerulescens & black-throated blue warbler & & & $\mathrm{C}$ \\
\hline Dendroica cerulea & cerulean warbler & & NM & $\mathrm{C}$ \\
\hline Dendroica discolor & prairie warbler & & & $\mathrm{C}$ \\
\hline Egretta caerulea & little blue heron & & NM & \\
\hline Egretta thula & snowy egret & & NM & \\
\hline Falco peregrinus & peregrine falcon & d & $\mathrm{E}$ & \\
\hline Haliaeetus leucocephalus & bald eagle & $\mathrm{T}^{\mathrm{e}}$ & NM & \\
\hline Helmitheros vermivorus & worm-eating warbler & & & $\mathrm{C}$ \\
\hline Hylocichla mustelina & wood thrush & & & $\mathrm{C}$ \\
\hline Lanius ludovicianus & loggerhead shrike & & NM & \\
\hline Oporornis formosus & Kentucky warbler & & & $\mathrm{C}$ \\
\hline Pooecetes gramineus & vesper sparrow & & NM & \\
\hline Protonotaria citrea & prothonotary warbler & & & $\mathrm{C}$ \\
\hline Seiurus motacilla & Louisiana waterthrush & & & $\mathrm{C}$ \\
\hline Sitta pusilla & brown-headed nuthatch & & & $\mathrm{C}$ \\
\hline Sphyrapicus varius & yellow-bellied sapsucker & & NM & \\
\hline Spizella pusilla & field sparrow & & & $\mathrm{C}$ \\
\hline Vermivora chrysoptera & golden-winged warbler & & NM & $\mathrm{C}$ \\
\hline Vermivora pinus & blue-winged warbler & & & $\mathrm{C}$ \\
\hline \multicolumn{5}{|c|}{ MAMMALS } \\
\hline Myotis grisescens & gray bat & $\mathrm{E}$ & $\mathrm{E}$ & \\
\hline Myotis sodalis & Indiana bat $^{\mathrm{f}}$ & $\mathrm{E}$ & $\mathrm{E}$ & \\
\hline Sorex longirostris & southeastern shrew & & NM & \\
\hline
\end{tabular}

${ }^{\mathrm{a}}$ Land and surface waters of the ORR exclusive of the Clinch River, which borders the ORR

${ }^{\mathrm{b}} \mathrm{E}=$ endangered, $\mathrm{T}=$ threatened, $\mathrm{NM}=$ in need of management, $\mathrm{C}=$ birds of concern

${ }^{\mathrm{c}}$ Partners in Flight

${ }^{\mathrm{d}}$ The peregrine falcon was federally delisted on August 25, 1999

${ }^{\mathrm{e}}$ The bald eagle was proposed for federal delisting on July 6, 1999

${ }^{\mathrm{f}}$ Reported collected on the ORR in the 1950s 
Table 4. Wildlife species recorded along the proposed Haul Road corridor. Species were identified by sight, song, call and/or sign.

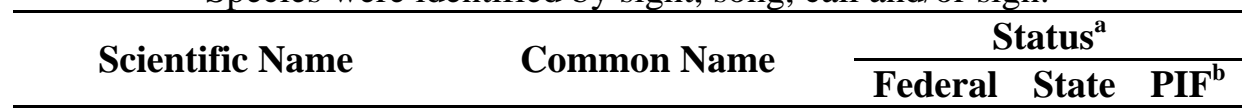

\section{AMPHIBIANS AND REPTILES}

Pseudacris feriarum

southeastern chorus frog

Cathartes aura

Buteo lineatus

Meleagris gallopavo

Colinus virginianus

Scolopax minor

Zenaida macroura

Coccyzus americanus

Sphyrapicus varius

Picoides pubescens

Dryocopus pileatus

Empidonax virescens

Vireo griseus

Vireo olivaceus

Cyanocitta cristata

Poecile carolinensis

Thryothorus

ludovicianus

Polioptila caerulea

Sialia sialis

Turdus migratorius

Geothlypis trichas

Pipilo erythrophthalmus

Spizella pusilla

Zonotrichia albicollis

Junco hyemalis

Cardinalis cardinalis

Passerina cyanea

Carduelis tristis

\section{BIRDS}

turkey vulture

red-shouldered hawk

wild turkey

northern bobwhite

American woodcock

mourning dove

yellow-billed cuckoo

yellow-bellied sapsucker

NM

downy woodpecker

pileated woodpecker

acadian flycatcher

white-eyed vireo

red-eyed vireo

blue jay

Carolina chickadee

Carolina wren

blue-gray gnatcatcher

eastern bluebird

American robin

common yellowthroat

eastern towhee

field sparrow

C

white-throated sparrow

dark-eyed junco

northern cardinal

indigo bunting

American goldfinch

\section{MAMMALS}

Marmota monax

woodchuck

Procyon lotor

raccoon

Sylvilagus floridanus

eastern cottontail

Odocoileus virginianus white-tailed deer

\footnotetext{
${ }^{\mathrm{a}} \mathrm{NM}=$ in need of management, $\mathrm{C}=$ species in need of conservation

${ }^{\mathrm{b}}$ Partners in Flight
} 
management by the State (Fig. 4) and is afforded a level of protection that requires that its habitat be protected and not knowingly destroyed. This dace is found in the Ridge and Valley province of Tennessee with limited populations; the population in the Bear Creek watershed has been indicated as one of the primary strongholds for the species in Tennessee (Etnier and Starnes 1993).

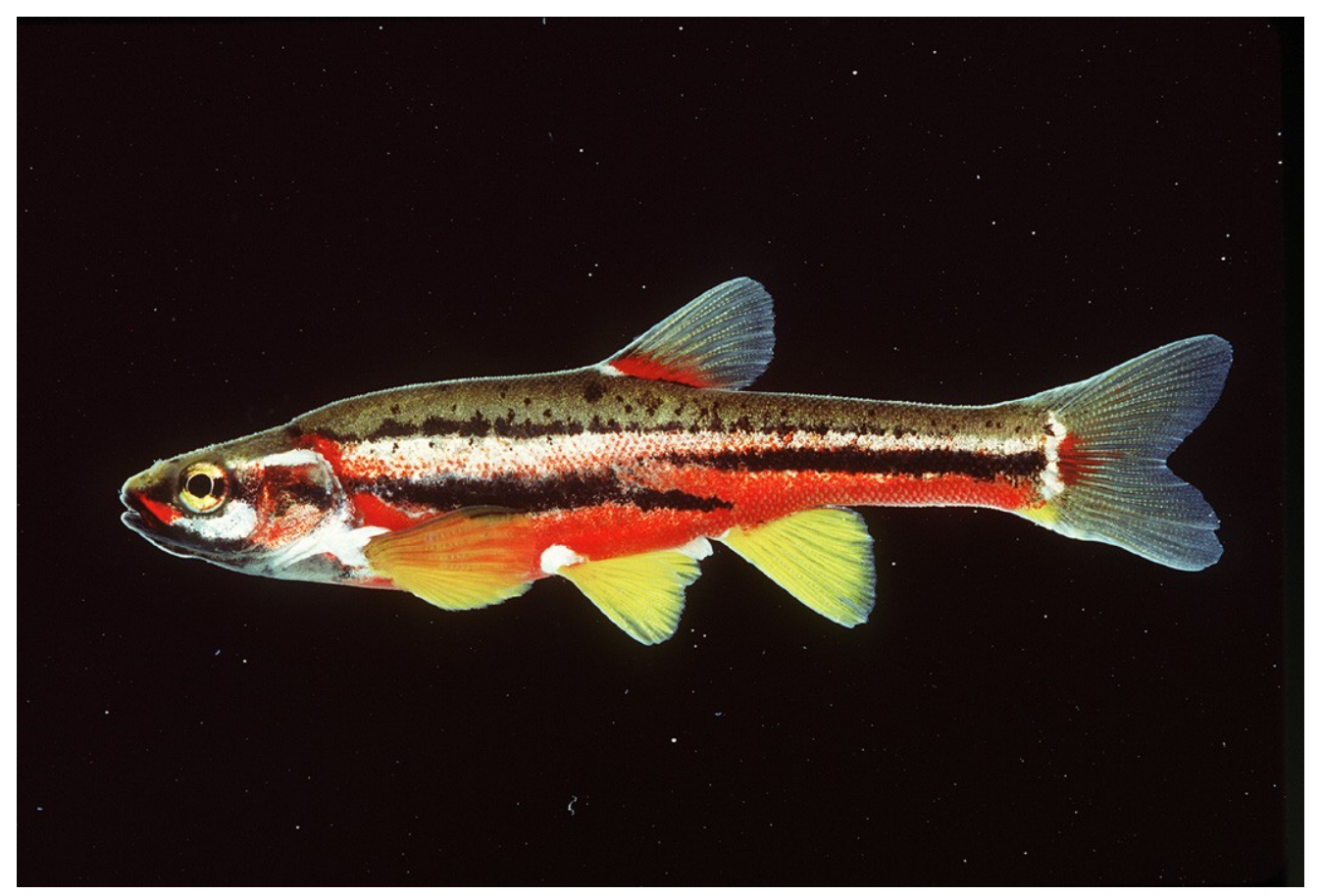

Fig. 4. Male Tennessee dace from Pinhook Branch, Oak Ridge Reservation, in spawning colors. Photo copyrighted by R. Bryant.

The reproductive biology of the Tennessee dace represents the most critical aspect of its life cycle that could be impacted by the ETTP Haul Road (see Appendix B for a detailed description of the species' reproductive biology). Several conditions are necessary for successful spawning of the Tennessee dace to occur. First, flow must be continuous throughout the spawning season (spring to early summer). Second, dace move into small streams during spawning and access for migration must be maintained throughout the watershed to allow for formation of aggregations. Long and dark culverts, or culverts that create a waterfall barrier, can be a barrier to fish movement. Thirdly, excess sedimentation to streams must be limited during the spawning season. Males of host species will continue to maintain a nest when sedimentation occurs, but if it is excessive, they will abandon nests. Extended periods of sedimentation can result in a total spawning failure for the year. Because Tennessee dace are short-lived, consecutive poor spawning seasons could have a detrimental effect on the overall population viability in a watershed.

As with most road construction, the ETTP Haul Road could impact streams primarily by reducing the amount of riparian cover and canopy, increasing the degree of sedimentation, and introducing barriers to fish movement. These issues are particularly important relative to the Tennessee dace in the Bear Creek watershed. Therefore, a number of road design features were incorporated into the Haul Road construction plan to avoid any impact to this species. Design features include bridging of Bear Creek and large tributaries where the species is present, and extra large culverts and design features that allow partial sediment filling and light infiltration into the culverts. Erosion control features will be implemented and 
closely monitored during construction. The dace acts as a sentinel species and design choices aimed at limiting impacts to the dace will also serve to limit impacts on the entire aquatic resource.

\section{Wetlands/Floodplains}

Floodplain or bottomland forest impacted by the Haul Road comprised 6.4 acres or approximately $12 \%$ of the total habitat (Table 1). The final road alignment avoided some of the higher quality and mature bottomland stands near Bear Creek Road, Gum Branch, and near the CAPCA Haul Road. Most of the forested floodplains within the Haul Road corridor contained a natural assemblage of wet-adapted trees and shrubs, but most trees were of young age ( $15-30$ years) due to past forestry practices in the area. Some bottomlands were on the wetter end of the scale due to past road construction and/or earth moving associated with the power-line along Pine Ridge. The largest and highest quality bottomland forest impacted by the Haul Road was found along Bear Creek, where large Sycamore (Platanus occidentalis), red maple (Acer rubrum), and sweetgum (Liquidambar styraciflua) were found. Bottomland forest is increasingly rare regionally, and some of the floodplain areas along Bear Creek Valley are some of the best examples of this community type.

The Haul Road corridor crosses 15 wetlands, comprising a total of 1.35 acres that contain the necessary soils, hydrology and plants to be considered jurisdictional wetlands (Figs. 5 and 6). Jurisdictional wetlands impacted by the Haul Road were typically found in flat areas adjacent to streams, within valleys or hollows, and supported in part by smaller streams, springs and seeps. Most of the wetlands were associated with streams that drain Pine Ridge into Bear Creek and Grassy Creek, with the largest wetland tracts found adjacent to Bear Creek, Gum Branch, and NT-13 (Table 5; Fig. 7). Only six of the 15 sites were forested, but forested wetlands comprised $67 \%$ of the total wetland acreage delineated. The nine marsh-like wetlands comprising 0.51 acres were found below power-lines and were kept herbaceous by occasional mowing.

Table 5. Wetland size and type within the Haul Road corridor.

Sites are listed in order encountered from near ETTP to the CAPCA Haul Road.

\begin{tabular}{clll}
\hline Site & Acreage & Wetland Type & \multicolumn{1}{c}{ Description } \\
\hline W1 & 0.002 & Forested wetland & Narrow wooded wetland adjacent to Mitchell Branch \\
W2 & 0.093 & Forested wetland & Flooded wetland adjacent to tributary stream \\
W3 & 0.050 & Forested wetland & Wooded wetland along flat shelf \\
W4 & 0.050 & Marsh & Herbaceous vegetation under power-line \\
W5 & 0.055 & Marsh & Herbaceous vegetation under power-line \\
W6 & 0.048 & Marsh & Herbaceous vegetation under power-line \\
W7 & 0.052 & Marsh & Herbaceous vegetation under power-line \\
W8 & 0.063 & Marsh & Herbaceous vegetation under power-line \\
W9 & 0.060 & Marsh & Herbaceous vegetation under power-line \\
W10 & 0.566 & Forested wetland & Swamp-like wetlands of high natural quality associated with \\
& & & small streams and seepage flow adjacent to Bear Creek \\
W11 & 0.020 & Forested wetland & Adjacent to Bear Creek tributary stream \\
W12 & 0.030 & Marsh & Herbaceous vegetation under power-line \\
W13 & 0.111 & Forested wetland & Two areas connected hydrologically, one forested seep \\
& & & wetland and one marsh; high quality wetlands in area adjacent \\
& & & to Gum Branch (NT-14) \\
W14 & 0.056 & Marsh & Under power-line \\
W15 & 0.095 & Marsh & Under power-line; two areas divided by road; near CAPCA \\
& & & Haul Road. \\
\hline TOTAL & 1.351 & & \\
\hline
\end{tabular}



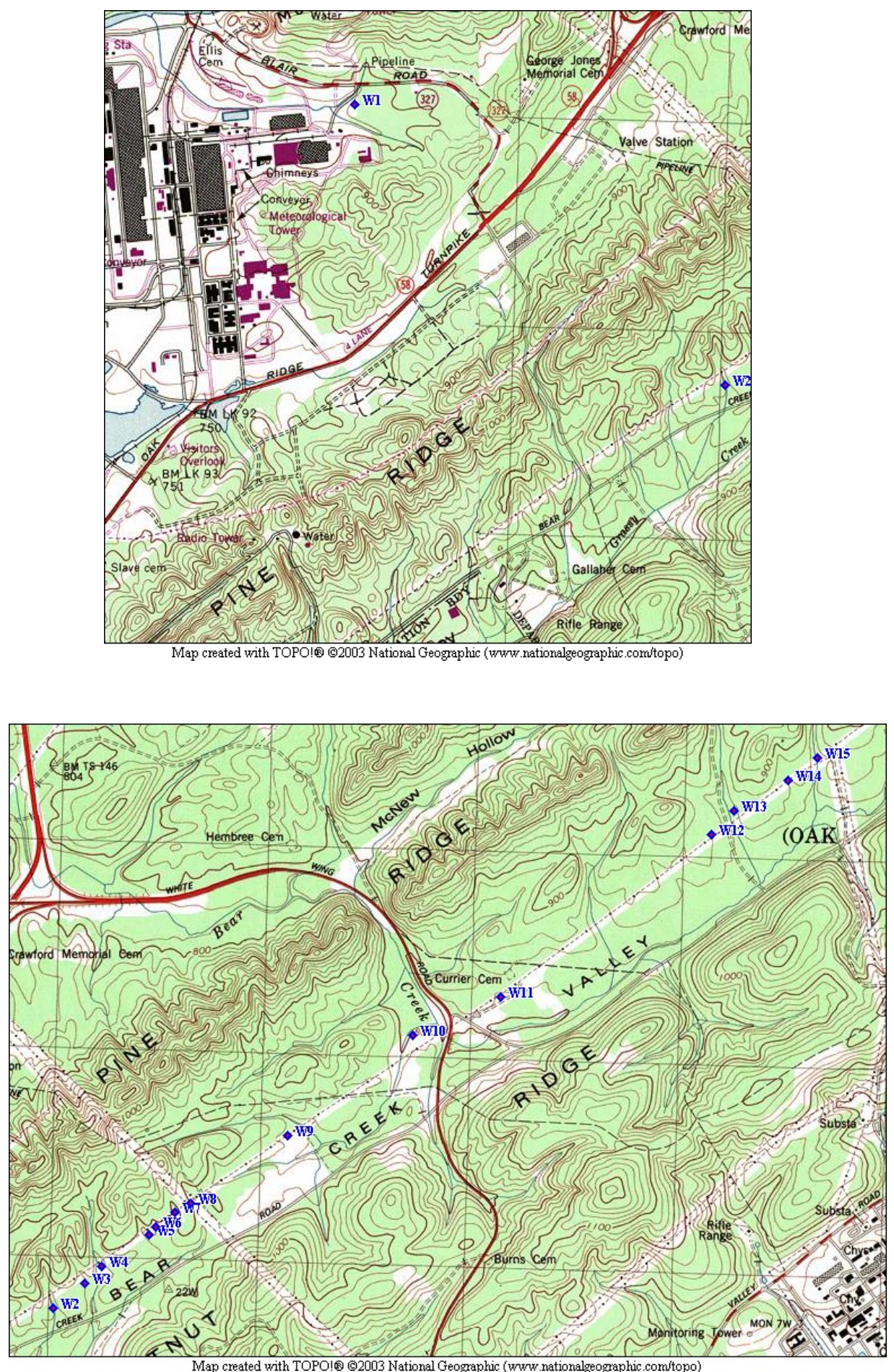

Fig. 5. Topographic map showing location of 15 wetlands (W1-W15) delineated within the ETTP Haul Road corridor. 

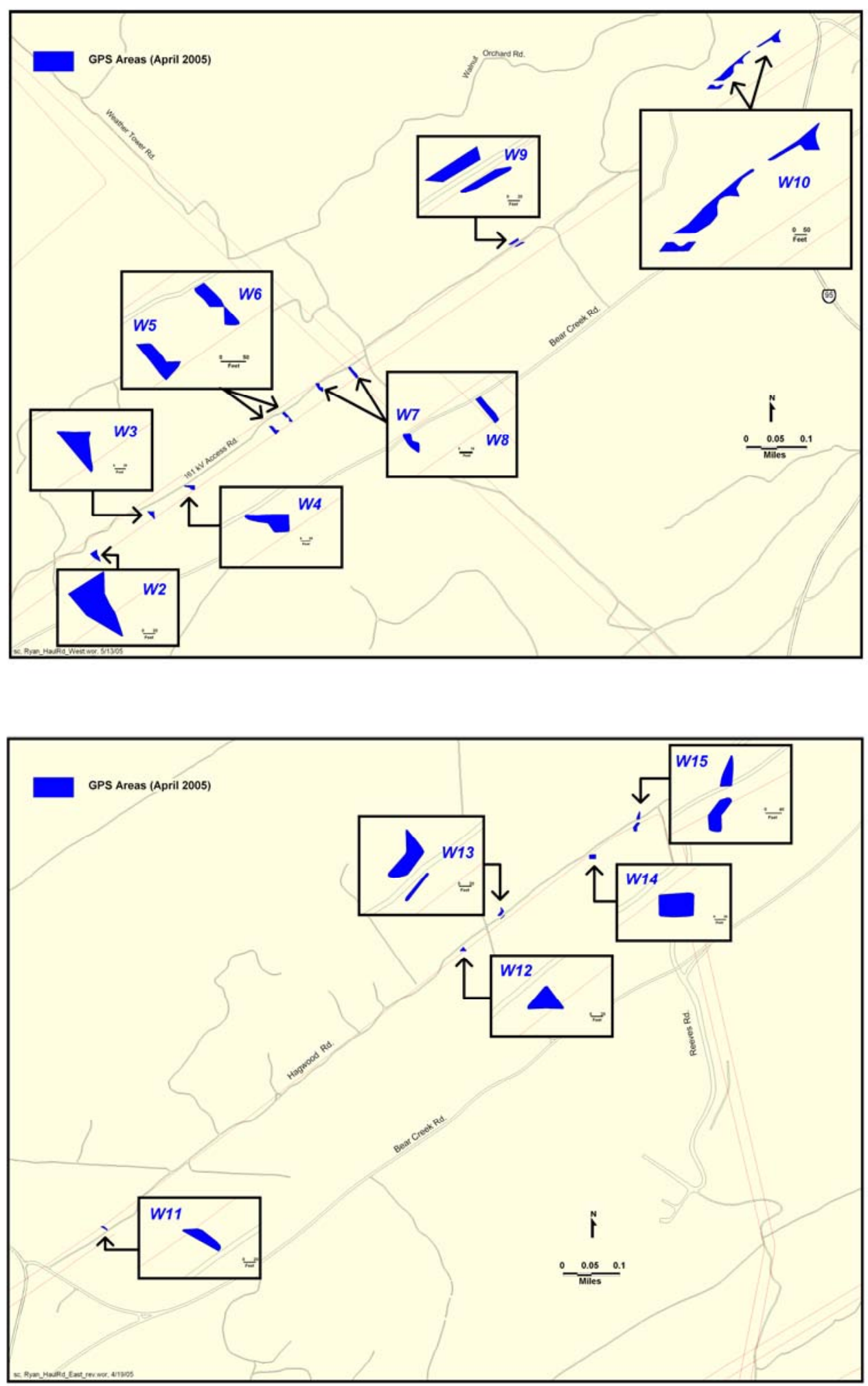

Fig. 6. General size and shape of delineated wetlands along Pine Ridge.

Top map shows the Flannigan Loop to Route 95 section; bottom map shows the Route 95 to CAPCA Haul Road section. Map by Sherri Cotter. 
A formal wetland determination was conducted for select sites and a representative determination report is provided in Table 6. For forested sites, plant identifications were possible for many trees and shrubs using bark characteristics or other traits associated with branches or buds. Trees adapted to sustained wet conditions that were found within the Haul Road corridor include black willow, blue beech, hackberry, sugarberry, sycamore, red maple, and green ash. Wetland shrubs included spicebush and alder. A few early-season wetland herbs were encountered within the Haul Road corridor and are presented in Appendix C. Some herbaceous wetland plants remain green and present throughout the winter, most notably soft rush (Juncus effusus). However, Juncus is extremely hardy and will take advantage of areas with limited water, and so can be a poor indicator of the presence of jurisdictional wetlands. Many wet areas were crossed by the Haul Road but, upon evaluation of site soils, were not considered jurisdictional. Typically these areas were on sloping ground that was disturbed due to previous earth moving and exhibited little or no wetland soil development.

Wetland delineation surveys in winter, when herbaceous vegetation can be scarce, must often focus on hydrologic and soil indicators. Soil cores provided clear differentiation between wetland and non-wetland sites, and were used extensively to determine wetland boundaries impacted by the Haul Road, particularly for marsh sites. Wetland soils exhibited characteristics such as low chroma colors, gleying, and mottling. Wetland and nearby non-wetland soils are contrasted in Fig. 8.

Wetland hydrology for wetland sites within the Haul Road corridor is likely maintained by the flat terrain associated with terraced ridge-side slopes and valley bottoms, high water flooding from adjacent creeks, and spring and seep flow. At some sites wet conditions appear to be maintained by old power-line maintenance road construction that backs up stream and shallow groundwater flow.

\section{CONCLUSIONS}

In summary, the Haul Road route traverses a wide variety of habitats, with three quarters of the impacted area consisting of disturbed or very common habitat types. Over half of those non-sensitive areas were comprised of highly developed areas like roads, mowed grasses, and power-line areas. The other non-sensitive habitat types were in various early successional stages, and include habitats such as old fields, woody thickets, forest edge communities, and planted loblolly pine areas. More regionally sensitive habitats found within the Haul Road route included a variety of forest types. These included approximately 6.4 acres of bottomland forest and 4 acres of mixed or mixed-pine deciduous forest. Forested and marsh wetlands within the Haul Road corridor comprised 1.35 acres of jurisdictional wetland habitat.

The most significant natural resource disturbance associated with the Haul Road's construction is undoubtedly the potential aquatic and wetland impacts near Bear Creek and its major tributaries [NT-13, NT-14 (Gum Branch), NT-15, and a western tributary]. Bear Creek and its major tributaries contain the rare Tennessee dace, and forested wetlands adjacent to these streams were generally found to be of high natural quality. Fragmentation of interior forest was also a concern as road construction was deemed a potential impact on forest-interior neotropical migrant birds. However, a thorough review of past records as well as the present surveys found no evidence of rare, threatened or endangered wildlife species or plants present within the Haul Road corridor. 
Table 6. Routine wetland determination data for forested wetland site near Bear Creek, within the proposed route of the ETTP-EMWMF Haul Road corridor, as determined on

March 23, 2005. Completion per Army Corps of Engineers wetland determination protocols.

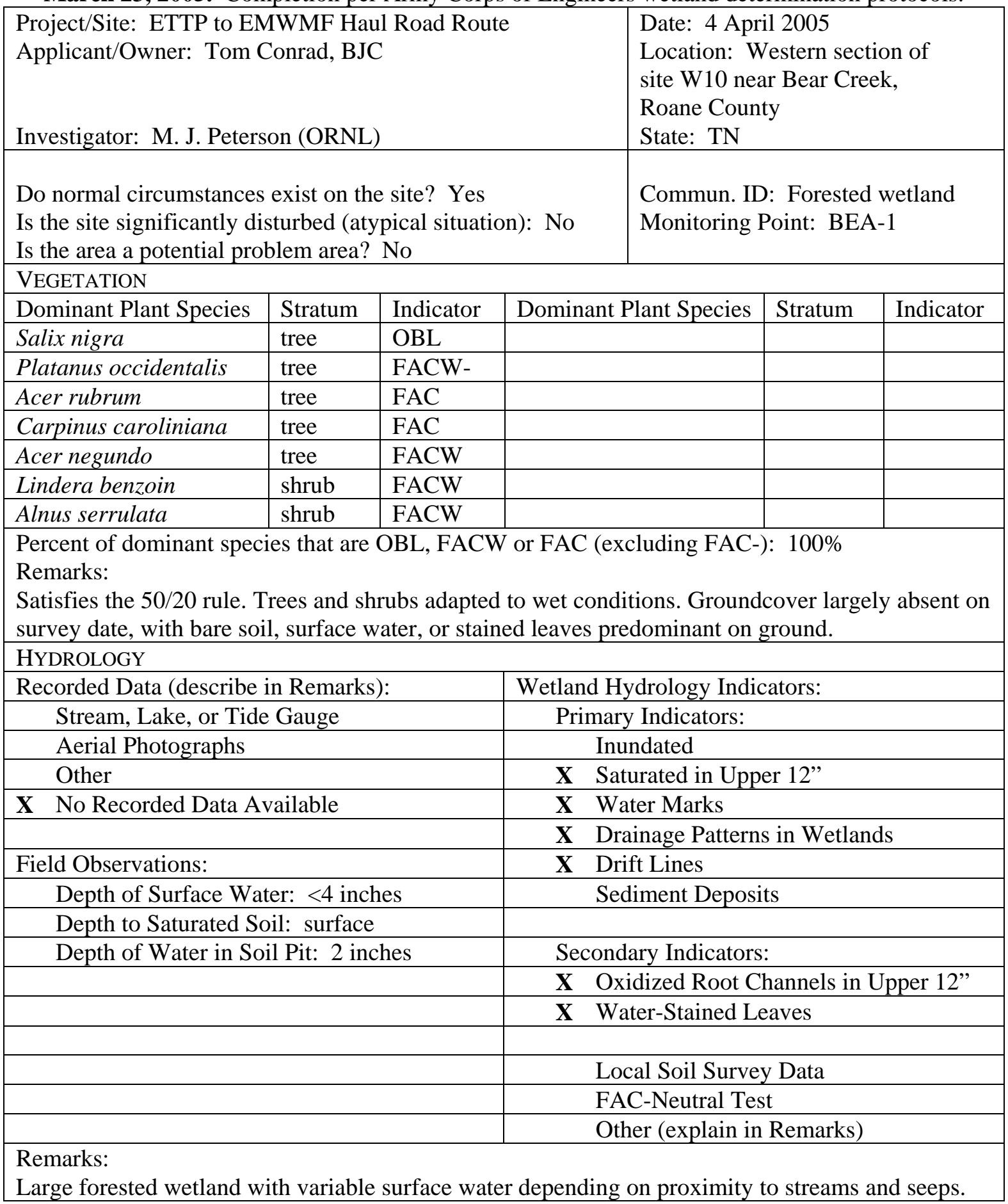


Table 6. Continued

SOILS

Classification:

Fine, silty to clayey loam, mixed, thermic, Typic Endoaqualf. Such hydric soils are characteristic of Pine Ridge terraces and shallow sloped tributary areas (4-6\% slope) of Bear Creek valley.

Surrounding soils on the 25-60\% slopes are Armuchee-Muskingum complex (Anderson County Soil Survey). Highly organic, fibrous root material in A horizon. All soils in this area of Pine Ridge underlain by multicolored shale, siltstone, and sandstone. Shallow soils in some areas, with little or no horizon development below the B horizon. Underlaying rock at surface in some steeper areas (i.e., little or no soil).

Profile Description:

\begin{tabular}{|c|c|l|l|l|l|}
\hline $\begin{array}{c}\text { Depth } \\
\text { (in.) }\end{array}$ & Horizon & $\begin{array}{c}\text { Matrix } \\
\text { Color }\end{array}$ & $\begin{array}{c}\text { Mottle } \\
\text { Colors }\end{array}$ & $\begin{array}{c}\text { Mottle } \\
\text { Abundance/Contrast }\end{array}$ & $\begin{array}{c}\text { Texture, Concretions, } \\
\text { Structures }\end{array}$ \\
\hline $0-8 ”$ & A & 10YR 4/2 & none & none & Organic, fibrous roots \\
\hline $8-16 ”$ & B & $\begin{array}{l}\text { Gley 1, } \\
410 Y\end{array}$ & 2.5 YR 5/6 & $20 \%$ of matrix & $\begin{array}{l}\text { Very fine granular, silty } \\
\text { to sandy loam }\end{array}$ \\
\hline
\end{tabular}

\begin{tabular}{|c|c|}
\hline \multicolumn{2}{|l|}{ Hydric Soil Indicators: } \\
\hline Histosol & $\mathbf{X}$ Concretions \\
\hline Histic Epipedon & High Organic Content in Surface Layer Sandy Soils \\
\hline Sulfidic Odor & Organic Streaking in Sandy Soils \\
\hline $\mathbf{X}$ Aquic Moisture Regime & Listed on State Hydric Soils List \\
\hline $\mathbf{X}$ Reducing Conditions & Listed on National Hydric Soils List \\
\hline $\mathbf{X}$ Gleyed or Low-Chroma Colors & Other (explain in Remarks) \\
\hline \multicolumn{2}{|c|}{$\begin{array}{l}\text { Remarks: } \\
\text { Soils show strong evidence of sustained wet conditions. Fragmented shale at } 16 ” .\end{array}$} \\
\hline \multicolumn{2}{|l|}{ WETLAND DETERMINATION } \\
\hline Hydrophytic vegetation present? & YES \\
\hline Wetland hydrology present? & YES \\
\hline Hydric soils present? & YES Is this sampling point within a wetland? \\
\hline
\end{tabular}



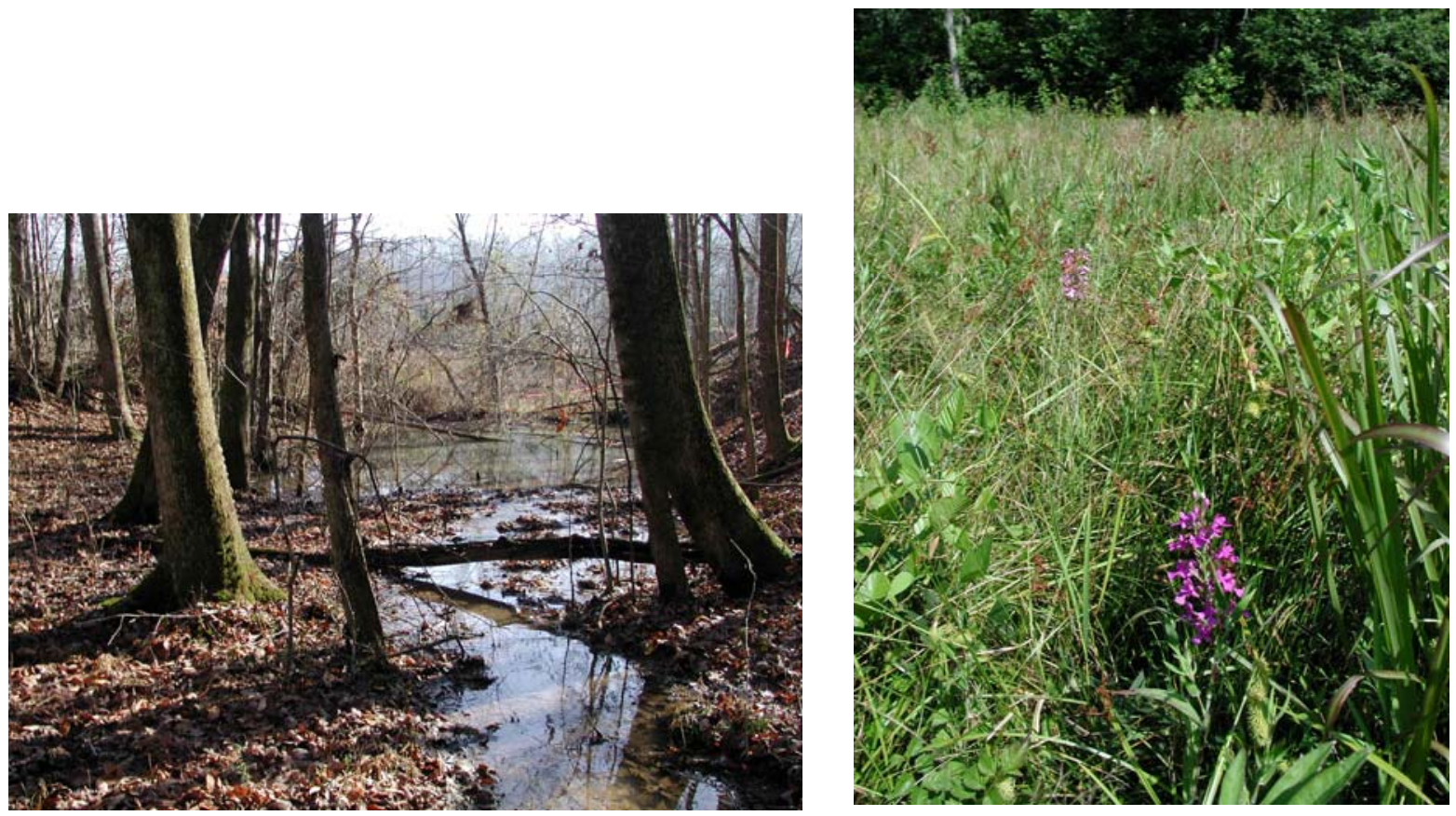

Fig. 7. Photos of common wetland types (left-forested wetland; right-marsh) encountered along the Haul Road route.
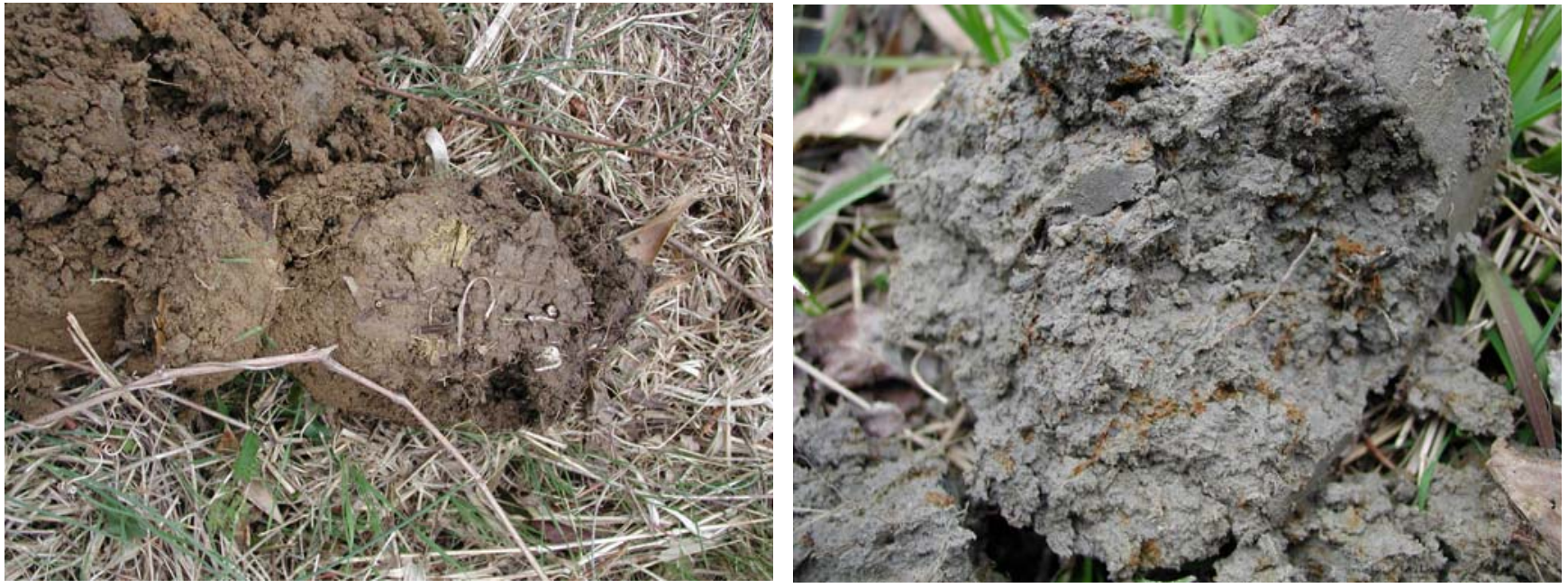

Fig. 8. Contrast between commonly encountered non-wetland soil (left) and wetland soil (right) surveyed within the Haul Road route. The strong gleying (right) is characteristic of sustained wet conditions. The orange streaks are oxidized rhizomes. 
Oak Ridge National Laboratory natural resource staff worked closely with the design engineers on this project to avoid impacts to sensitive resources to the extent possible. Following is a list of major project actions undertaken or planned to avoid negative impacts to sensitive resources:

- Multiple road alignment changes were made to avoid impacts to rare plants, streams, wetlands, and mature forest tracts:

0 Forest fragmentation was minimized by following the existing power-line to the extent possible, avoiding large forest tracts within proposed routes north of Pine Ridge and near Bear Creek Road;

o A large Mitchell Branch wetland was avoided and the alignment was shifted so that only one stream crossing was necessary instead of two;

o Rare orchids just north of Bear Creek Road were avoided by moving the alignment to the north of the existing power-line;

o Impacts to a mature bottomland forest near the CAPCA Haul Road were avoided by realignment to the north of the existing power-line;

o The extent of Bear Creek and Gum Branch wetlands impacted was minimized by a realignment that took advantage of slightly higher ground; and,

o Two stream crossings west of Bear Creek were changed to a single crossing with realignment.

- Trees along the Haul Road corridor were removed by March 31, 2005 to avoid potential negative impacts to Indiana bat habitat.

- Bridges (rather than culverts) will be used for the Bear Creek and Gum Branch crossings to avoid impacts to Tennessee dace. The Bear Creek bridge crossing, which includes State Route 95, was a significant design challenge and totally avoids disturbance to stream sediment and riparian areas.

- A bridge will be used to cross Mitchell Branch instead of a culvert, to minimize negative stream impacts.

- Special culvert designs will be used at some sites to enhance the fish's ability to traverse culverts.

In addition, various control measures will be taken during road construction to minimize impacts to streams and wet-weather conveyances, especially in the Bear Creek tributaries that contain Tennessee dace. Early actions, associated with tree clearing activities, included the extensive use of silt fencing and the grinding of trees to create mulch that was used to provide ground cover and soil stabilization benefits. Details of future control actions associated with road construction are provided in the project's Environmental Monitoring Plan and the project-specific Remedial Design Report (DOE/OR/01-2228) and are not repeated here. Major actions include following erosion control and sediment prevention techniques detailed in the appropriate SWPPP, TDEC BMP guidelines, and the Haul Road construction specifications.

Site-specific control measures to be taken that are of particular importance to protecting the Tennessee dace include using appropriately sized culverts and box bridges to prevent the impoundment of normal and base flows; using box bridges where appropriate to minimize impacts to existing streams with sensitive habitat; and designing specific oversized, partially submerged culverts with light infiltration to maintain and support fish movement. In addition to the design of crossings, the timing of Haul Road construction in mid to late summer should avoid critical periods when migration and reproductive activities of the Tennessee dace are at a peak. 
To the extent possible, wetlands will be created at a 2:1 ratio during the Haul Road construction to compensate for wetland losses from the project. A Wetland Mitigation Plan, detailing the compensatory activities to be conducted, will be provided to regulatory authorities in the summer of 2005. Out-of-kind mitigation that enhances sensitive resources may be considered for this project.

Measures will be taken to prevent the spread of invasive species on the cleared areas adjacent to the gravel Haul Road. Species such as kudzu, Nepal grass, Russian olive, lespedeza, and privet are just some of the invasive plants that can become established immediately after soil disturbance. Use of native plants in re-vegetating side slopes is one possibility for preventing the spread of invasive plants.

Alternatively, not all areas could be seeded/ re-vegetated. Application of straw (not hay) and use of silt fences could be adequate in many areas, and would allow native species to grow back to the road. Fire ants are a recent problem in construction zones and have been encountered along the Haul Road route, and may need to be controlled shortly after construction. ORNL natural resource staff will work together with project compliance personnel to prevent or minimize the spread of invasive species and conduct any control treatments if necessary. 


\section{REFERENCES}

ACOE (Army Corps of Engineers). 1987. Wetlands Delineation Manual. U.S. Army Corps of Engineers. Technical Report Y-87-1. Waterways Experiment Station, Vicksburg, MS.

Britzke, E. R., M. J. Harvey, and S. Loeb. 2003. Indiana bat, Myotis sodalis, maternity roosts in the southern United States. Southeastern Naturalist 2(2):235-242.

Callahan, E. V., R. D. Drobney, and R. L. Clawson. 1997. Selection of summer roosting sites by Indiana bats (Myotis sodalis) in Missouri. Journal of Mammalogy 78:818-825.

Etnier, D. A. and W. C. Starnes. 1993. The Fishes of Tennessee. University of Tennessee Press, Knoxville, TN.

Gardner, J. E., J. D. Garner, and J. E. Hofmann. 1991. Summer roost selection and roosting behavior of Myotis sodalis (Indiana bat) in Illinois. Final Report. Illinois Natural History Survey and Illinois Department of Conservation, Champaign, IL. 56 pp.

Harvey, M. J., J. S. Altenbach, and T. L. Best. 1999. Bats of the United States. Arkansas Fish \& Game Commission in cooperation with the Ashville Field Office, U.S. Fish and Wildlife Service. 64 pp.

Hinzman, R. L. (ed.). 1996. Report on the Biological Monitoring Program for Bear Creek at the Oak Ridge Y-12 Plant, Oak Ridge, Tennessee (1989-1994). ORNL/TM-12884. Oak Ridge National Laboratory, Oak Ridge TN.

Kurta, A., K. J. Williams, and R. Mies. 1996. Ecological, behavioral, and thermal observations of a peripheral population of Indiana bats (Myotis sodalis). pp. 102-117. IN R. M. R. Barclay and R. M. Brigham (eds.). Bats and Forest Symposium. British Columbia Ministry of Forests, Victoria, BC, Canada. 292 pp.

Letter from Lee A Barklay (USFWS) to James Elmore (Department of Energy) concerning guidelines for avoiding disturbance to Indiana bat habitat. Letter Correspondence, October 13, 2004.

Mann, L. K., P. D. Parr, L. R. Pounds, and R. L. Graham. 1995. Protection of Biota on Nonpark Public Lands: Examples from the U.S. Department of Energy Oak Ridge Reservation. Environmental Management 20(2):207-218.

Munsell Company. 1994. Munsell Soil Color Charts (revised edition). Munsell Color Company, New Windsor, NY.

Settles, W. H. and R. D. Hoyt. 1978. The reproductive biology of the southern redbelly dace, Chrosomus erythrogaster Rafinesque, in a spring-fed stream in Kentucky. Am. Midl. Natur. 99(2):290-298.

Southworth, G. R., J. M. Loar, M. G. Ryon, J. G. Smith, A. J. Stewart, and J. A. Burris. 1992. Ecological effects of contaminants and remedial actions in Bear Creek. ORNL/TM-11977. Oak Ridge National Laboratory, Oak Ridge, TN.

Starnes, W. C. and R. E. Jenkins. 1988. A new cyprinid fish of the genus Phoxinus (Pisces: Cypriniformes) from the Tennessee River drainage with comments on relationships and biogeography. Proc. Biol. Soc. Wash. 101(3):517-529. 
U.S. Fish and Wildlife Service (USFWS). 1997. 1988 National and Southeastern List of Vascular Plant Species that Occur in Wetlands. U.S. Fish and Wildlife Service. http://www.nwi.fws.gov/ecology.htm. (last modified March 3, 1997).

U.S. Fish and Wildlife Service (USFWS). 1999. Agency draft Indiana bat (Myotis sodalis) revised recovery plan. Fort Snelling, MN. 53 pp. 
APPENDIX A

RARE PLANT AND WILDLIFE SURVEY 



\section{APPENDIX A. \\ RARE PLANT AND WILDLIFE SURVEY}

The existing plant communities and wildlife habitat was surveyed along the entire Haul Road route during multiple field visits from November 2004 through late March of 2005, with an emphasis on determining if rare species were present. The boundaries of the plant communities/habitat were identified by utilizing existing haul road survey markers. A summary of the surveys is provided below, starting with the Portal 5 area near ETTP and finishing near the CAPCA Haul Road.

\section{SEGMENT ONE - ETTP to Bear Creek Road}

Survey Marker 206+00 to 212+00 - This area is characterized by a mixture of old field, thicket, spread gravel and mowed fescue areas. Plant species recorded in this area included eastern red cedar, privet, American ash, loblolly pine, Japanese honeysuckle, red maple, blackberry, cottonwood, broom-sedge, Chinese lespedeza and Nepal grass. Wildlife sign in this area included eastern cottontail (scat) and whitetailed deer (scat and tracks).

Survey Marker 212+00 to 217+00 - This is an area with heavy pine beetle damage with old field vegetation dominated by Japanese honeysuckle and blackberry. There are a number of standing snags with loose bark, along with significant areas with dead and down woody material. Trees with loose bark provide potential roosting habitat for the Indiana bat in the spring and summer.

Survey Marker 217+00 to Portal 6 - This area was not surveyed in detail because this segment is characterized by mowed fescue and paved areas.

Survey Marker 230+00 to 237+30 - This area is thicket. Plant species recorded in this area included eastern red cedar, smooth sumac, loblolly pine, American beech, sycamore, privet, Virginia pine, Chinese lespedeza and silver plumegrass. Wildlife and/or wildlife sign recorded in the area included blue-gray gnatcatcher (nest) and blue jay (call).

Survey Marker 237+30 to $241+30$ - This area is characterized by old field vegetation. Plant species recorded in this area included blackberry, goldenrod, Japanese honeysuckle, eastern red cedar, silver plumegrass, white pine, purpletop grass and thistle. Wildlife and/or wildlife sign recorded in the area included American robin (sighting).

Survey Marker 241+30 to 244+50 - This is an area of bottomland forest with some areas of wetland. Plant species recorded in this area included white oak, privet, black cherry, tulip poplar, white pine, red maple, sweetgum, sycamore, box elder and hackberry. There are also patches of Nepal grass in the ground cover. Wildlife and/or wildlife sign included pileated woodpecker (rectangular holes in snag).

Survey Marker 244+50 to 258+00 - This is a large old field area with patches of shrubs, young trees, eroded bare soil and seepage. Plant species recorded in this area included blackberry, smooth sumac, white pine, loblolly pine, goldenrod, privet, panic grass (two species), broom sedge, sweetgum, southern red oak, foxtail-grass, Japanese honeysuckle, soft rush and sycamore. Distinctive patches include a large area of broom sedge, and a large area of mixed white and loblolly pine. Wildlife and/or wildlife signs recorded included white-throated sparrow (sighting), eastern towhee (call), blue jay (call) and white-tailed deer (tracks). 
Survey Marker 258+00 to 261+00 - This area contains a narrow area of dense privet bordering an existing road of mowed grass (fescue). Other plant species recorded in this area included red maple and tulip poplar.

Survey Marker 261+00 to $263+10$ - This is a small area of young forest dominated by pines. There is only sparse understory and groundcover in this area. The area contains mainly Virginia and loblolly pines in the overstory. Other plant species recorded included red maple, southern red oak, eastern red cedar, pipsissewa and ground cedar.

Survey Marker 263+10 to Route 58 - This area is characterized by old field vegetation. Plant species recorded in this area included eastern red cedar, loblolly pine, blackberry, wild carrot, asters, Chinese lespedeza and silver plumegrass.

Route 58 to Survey Marker 270+40 - This area supports woods dominated mainly by white pine in the overstory. Other plant species recorded in this area included loblolly pine, eastern red cedar, sweetgum, pipsissewa and reindeer lichen. A band of young sweetgum is present on the southern edge of this area along what is apparently an old road.

Survey 270+40 to 272+50 - This area supports a young forest of deciduous tree species. Plant species recorded in this area included white oak, southern red oak, black cherry, black walnut, ash, privet, eastern red cedar, box elder, Japanese honeysuckle, poison ivy and Nepal grass.

Survey Marker 272+50 to 273+30 - This area supports a very narrow band of herbaceous vegetation that is mainly goldenrod and asters. The area is bordered immediately to the south by an unpaved road $(273+00$ to $273+30)$.

Survey Marker 273+30 to 276+20 - This is an area of young forest that is dominated mainly by box elder. Other plant species recorded in this area included privet, loblolly pine, hackberry, sweetgum, eastern red cedar, asters and silver plumegrass. This area also contained pine beetle damaged trees that could be potential roosting habitat for Indiana bats.

Survey Marker 276+20 to Flannigan Loop Road - This is a young forest of dense loblolly pine.

Flannigan Loop Road from North to South Gate - Flannigan Loop Road was driven from the north gate to the south gate to evaluate any potential concerns. The main concern is the potential loss of large hardwood trees, resulting from the road widening. Tree species here include southern red oak, northern red oak, white oak, tulip poplar, beech and white pine. There are large trees in the vicinity of the roadway that could be impacted by the road widening. There were no large hardwood trees noted in the path of the widening with exfoliating (peeling) bark. Therefore, it is not expected that any potential roosting habitat for the Indiana bats will be impacted.

\section{SEGMENT TWO-Flannigan Loop Road to Route 95 Segment}

Survey Marker 313+00 to 319+40 - This is an area with heavy pine beetle damage, consisting of mainly dead pine with a mixture of other live plant species. Plant species recorded in this area included eastern red cedar, Japanese honeysuckle, mountain mint, flowering dogwood, thistle, Nepal grass, blackberry, slippery elm, panic grass, silver-plumegrass, sweetgum, southern red oak, privet, greenbrier and black cherry. Bird species noted in the area included Carolina wren and mourning dove. Trees with loose bark provide potential roosting habitat for the Indiana bat in the spring and summer. 
Survey Marker 319+40 to 321+30 - This is a wooded area with some larger dead pines. Plant species recorded in this area included privet, Nepal grass, Christmas fern, black cherry, tulip poplar, eastern red cedar, sweetgum, elephant foot and ebony spleenwort. There is also a small wet area by some very large downed trees that supports sedges, rushes and alternate-leaved seedbox. Bird species recorded in the area included red-shouldered hawk (flyover) and downy woodpecker. Trees with loose bark provide potential roosting habitat for the Indiana bat in the spring and summer.

Survey Marker 321+30 to 321+50 - This is an area of mainly small loblolly pines bisected by a gravel road. Japanese honeysuckle is common here. Bird species noted in the area included Carolina chickadee.

Survey Marker 321+50 to 326+80 - This is an area of mainly small loblolly pines. Other plant species recorded in this area included poverty grass, broomsedge grass, goldenrod, Japanese honeysuckle, reindeer lichen, red maple, boxelder and heart's-a-busting. Wildlife and/or wildlife sign recorded in the area included white-tailed deer trails.

Survey Marker 326+80 to 329+70 - This area is an area of bottomland forest. Plant species recorded in this area included sycamore, southern red oak, eastern red cedar, American beech, putty root orchid, sweetgum, Japanese honeysuckle, grape fern, Nepal grass, black cherry, American holly, red maple and ironwood. Wildlife and/or wildlife sign recorded in the area included chorus frogs (singing), a groundhog burrow and crayfish burrows.

Survey Marker 329+70 to 330+90 - This is an open area with heavy pine beetle damage, consisting of mainly dead pine with a mixture of other live plant species. Other plant species recorded in this area included black cherry, sweetgum and Japanese honeysuckle. Trees with loose bark provide potential roosting habitat for the Indiana bat in the spring and summer.

Survey Marker 330+90 to 332+30 - This area is a mowed power-line corridor. There is a small wet area close to Bear Creek Road on that east side of the power-line corridor that includes some rushes and sedges. Chorus frogs were recorded singing in this wet area. Other wildlife and/or wildlife sign recorded included white-tailed deer (tracks) and eastern cottontail (scat).

Survey Marker 332+30 to 335+00 - This is an area of scattered dead pines. Other plant species recorded in this area included live loblolly pine, Japanese honeysuckle, sweetgum and eastern red cedar.

Survey Marker 335+00 to 338+50 - This is a small savannah-like area of mainly loblolly pine with sparse areas of broomsedge grass. Other plant species recorded included eastern red cedar, Chinese lespedeza, Japanese honeysuckle, goldenrod, reindeer lichen, poverty grass, panic grass, blackjack oak, sweetgum, Virginia pine, privet and Christmas fern.

Survey Marker 338+50 to 339+00 - This area is a thicket containing mainly sweetgum and red maple. Other plant species recorded included flowering dogwood and Japanese honeysuckle.

Survey Marker 339+00 to 340+80 - This area contains a bottomland forest. Plant species recorded in this area included white oak, southern red oak, eastern red cedar, red maple, sweetgum, tulip poplar, Christmas fern and ground cedar. Chorus frogs were recorded singing in this area.

Survey Marker 340+80 to $345+50$ - This area is part mowed power-line corridor and part edge habitat. Plant species noted in the edge habitat included loblolly pine, Virginia pine, broomsedge grass and Japanese honeysuckle. White-tailed deer tracks were noted in the power-line corridor. 
Survey Marker 345+50 to 347+30 - This area contains a bottomland forest. Plant species recorded in this area included sweetgum, red maple, sycamore, woolgrass bulrush, rush, Nepal grass, Agrimony and Japanese honeysuckle. Chorus frogs were recorded singing in this area.

Survey Marker 347+30 to 347+40 - This is an area containing mainly rushes and sedges.

Survey Marker 347+40 to $348+50$ - This is an area of mowed power-line corridor.

Survey Marker 348+50 to 349+70 - This area contains a bottomland forest. Plant species recorded in this area included sweetgum, red maple, sycamore, loblolly pine, white pine, eastern red cedar, greenbrier, Japanese honeysuckle, Christmas fern, blackberry, cranefly orchid, rushes and sedges.

Survey Marker 349+70 to 350+70 - This area contains mainly rushes and sedges.

Survey Marker 350+70 to 368+00 - This is an area of mainly mowed power-line corridor. The area also contains some wet areas that contained singing chorus frogs.

Survey Marker 368+00 to 373+00 - This is an area of mowed power-line corridor. A pair of redshouldered hawks were noted in the area going through courtship. Potential bottomland forest nesting sites for this species exist in the vicinity of the power-line corridor. (Note: No red-shouldered hawk nests or nesting activity were recorded in any nearby forested areas that would be impacted by the haul road).

Survey Marker 373+00 to 379+00 - This area contains a gravel road, mowed power-line corridor and some old field. (There is one small wet area containing mostly common rush north of the gravel road.) Other plant species in this area include loblolly pine, sweetgum, smooth sumac, blackberry, Japanese honeysuckle, goldenrod, broomsedge grass and asters. A field sparrow and a northern cardinal were noted singing in the area.

Survey Marker 379+00 to 381+20 - This area contains a loblolly pine plantation. (There is also one small area of cattails and common rush.) Plant species recorded in the area included loblolly pine, red maple, sweetgum, tulip poplar, eastern red cedar, Japanese honeysuckle, panic grass, common rush and cattail.

Survey Marker 381+20 to $383+80$ - The area contains mainly old field and a gravel road. Plant species recorded in this area included loblolly pine, Virginia pine, eastern red cedar, sweetgum, blackberry, Japanese honeysuckle, poverty grass, broomsedge grass, goldenrod and reindeer lichen.

Survey Marker $383+80$ to $386+00$ - This area contains a mixture of old field and wetlands. Plant species recorded in this area included red maple, Japanese honeysuckle, blackberry, panic grass, alternateleaved seedbox, woolgrass bulrush and sedges.

Survey Marker 386+00 to 387+00 - This area contains old field and a gravel road. Plant species recorded in the area included loblolly pine, black cherry, flowering dogwood, blackberry, Japanese honeysuckle and broomsedge grass. Chorus frogs were noted singing in the vicinity. One turkey vulture was recorded as a flyover.

Survey Marker 387+00 to 389+00 - This area contains a bottomland forest, an area of mowed grass and a gravel road. The area also contains a creek. Plant species recorded in the area included tulip poplar, red maple, blackjack oak, American beech, loblolly pine, Nepal grass and spring-cress. The area has a lot of 
dead and downed woody material. One tree in the area had distinctive horizontally arranged drill holes from the activities of a yellow-bellied sapsucker.

Survey Marker 389+00 to 403+00 - This area contains a loblolly pine plantation and mowed power-line corridor. There is also one small wet area containing common rush and alder. One northern cardinal was noted singing in the area.

Survey Marker 403+00 to 404+00 - This area contains a wooded thicket and some bottomland forest. Plant species recorded included loblolly pine, blackjack oak, American beech, tulip poplar, red maple, sourwood, ebony spleenwort and cranefly orchid.

Survey Marker 404+00 to 405+90 - This is an area with heavy pine beetle damage, consisting of mainly dead pine with a mixture of other live plant species. Plant species recorded in this area included American holly, flowering dogwood, tulip poplar, eastern red cedar, blackberry, Japanese honeysuckle, Christmas fern and Nepal grass. The area also contains a lot of dead and down woody material. Trees with loose bark provide potential roosting habitat for the Indiana bat in the spring and summer.

Survey Marker 405+90 to Route 95 - This area contains bottomland forest. Plant species recorded in this area included tulip poplar, sycamore, alder, red maple, white oak, eastern red cedar, sweetgum, white pine, loblolly pine, blackberry, Japanese honeysuckle, crossvine, spring-cress, green ash and common rush. Bird species recorded in the area included Carolina Chickadee, field sparrow, eastern towhee, Carolina wren and dark-eyed junco. Chorus frogs were also noted singing in the area.

\section{SEGMENT THREE - Route 95 to CAPCA Haul Road}

Survey Marker 418+50 to $431+00$ - This is an area with heavy pine beetle damage, consisting of mainly dead pine with a mixture of other live plant species. Plant species recorded in this area included loblolly pine, eastern red cedar, blackberry, Japanese honeysuckle and goldenrod. Chorus frogs were noted singing in the vicinity of survey marker $426+00$. Trees with loose bark provide potential roosting habitat for the Indiana bat in the spring and summer.

Survey Marker 431+00 to 431+60 - This is an area of forest/thicket. Plant species recorded in this area included tulip poplar, white oak, eastern red cedar, greenbrier and Japanese honeysuckle.

Survey Marker 431+60 to $433+50$ - This is a wooded area containing mainly loblolly pine, Virginia pine and eastern red cedar.

Survey Marker 433+50 to 436+20 - This area contains a bottomland forest. Plant species recorded in the area included sycamore, sweetgum, southern red oak, white oak, American beech, nut-rush and flowering dogwood. Pileated woodpecker drillings were noted on one downed pine. There were large dead trees with peeling bark noted in the vicinity of survey marker $435+00$ to $435+20$. This was noted as potential Indiana bat roosting habitat.

Survey Marker 436+20 to 437+30 - This area contains a wooded thicket. Plant species recorded in this area included tulip poplar, black cherry, sweetgum, red maple, flowering dogwood, Japanese honeysuckle, striped pipsissewa and rattlesnake plantain. Survey marker $437+30$ to $438+00$ contains a small utility line. The utility line contained mainly grasses, including panic grass. 
Survey Marker $\mathbf{4 3 8 + 0 0}$ to $\mathbf{4 4 5 + 0 0}$ - This is an area with heavy pine beetle damage, consisting of mainly dead pine (mainly loblolly pine) with a mixture of other live plant species. Part of the area is mowed power-line corridor. Plant species recorded in this area included loblolly pine, Virginia pine, tulip poplar, eastern red cedar, red maple, sweetgum, Japanese honeysuckle, ground cedar and Nepal grass. The area contained a lot of dead and down woody material. One eastern cottontail and one white-breasted nuthatch were noted in the area. Trees with loose bark provide potential roosting habitat for the Indiana bat in the spring and summer.

Survey Marker 445+00 to $446+50$ - This area contains a bottomland forest with a creek. Plant species recorded in this area included red maple, alder, buckeye, ironwood, sweetgum, river cane, flowering dogwood, eastern red cedar, Japanese honeysuckle, greenbrier, wood rush, agrimony and Christmas fern.

Survey Marker 446+50 to 458+00 - This area is half mowed power-line and half wooded thicket. Plant species recorded in this area included loblolly pine, Virginia pine, red maple, white oak, hickory, ironwood, flowering dogwood, eastern red cedar, mockernut hickory and ground cedar.

Survey Marker 458+00 to $461+00$ - This area contains bottomland forest. Plant species recorded in this area included red maple, sourwood, white oak, and Christmas fern.

Survey Marker 461+00 to 465+00 - This is an area of mixed pine and deciduous woods. Plant species recorded in the area included loblolly pine, Virginia pine, tulip poplar, American beech, southern red oak and eastern red cedar.

Survey Marker $465+00$ to $467+00$ - This area contains mowed power-line corridor.

Survey Marker 467+00 to 472+50 (Gum Branch Road) - This area contains pines with mixed deciduous trees. Plant species recorded in this area included loblolly pine, sweetgum, red maple, eastern red cedar and Japanese honeysuckle. Chorus frogs were noted singing in one wet area. A dark-eyed junco was also sighted in this area.

Survey Marker 472+50 to 474+25 - This area contains bottomland forest with a creek. Plant species recorded in this area included tulip poplar, ironwood, red maple, redbud, black cherry, hackberry, multiflora rose, Japanese honeysuckle and rush.

Survey Marker 474+25 to 481+00 - This area is half deciduous woods and half mowed power-line. Plant species recorded in the area included red maple, American beech, white oak, eastern red cedar, broomsedge grass and common rush.

Survey Marker 481+00 to 483+50 - This area contains mowed power-line corridor. A Carolina chickadee was noted calling north of the site.

Survey Marker 483+50 to 485+00 - This area contains bottomland forest. Plant species recorded in this area included tulip poplar, white oak, eastern red cedar and loblolly pine. Chorus frogs were noted singing in the area.

Survey Marker $\mathbf{4 8 5 + 0 0}$ to $\mathbf{4 8 6 + 0 0}$ - This area is partially mowed and partially small saplings. Plant species recorded in this area included red maple and white oak.

Survey Marker 486+00 to CAPCA Haul Road - This area contains mowed power-line corridor. 
APPENDIX B

THE REPRODUCTIVE BIOLOGY OF THE TENNESSEE DACE 



\section{APPENDIX B. THE REPRODUCTIVE BIOLOGY OF THE TENNESSEE DACE}

The Tennessee dace (Phoxinus tennesseensis) generally prefers streams with pools and undercut bank structure, but must have access to riffle areas for spawning. The life span of Tennessee dace, as with most Phoxinus, is about three years, with spawning occurring in the second and third years. During most of the year, the dace are distributed throughout a stream watershed, at an average density of 1 fish per 10 $\mathrm{m}^{2}$ of water surface. During spawning activity, however, the dace migrate to form large aggregations. These migrations may cover large distances, as the number of individuals can reach several hundred fish or more in an aggregation.

The Tennessee dace typically spawns using nests built by other cyprinid species. These minnow species can include creek chub (Semotilus atromaculatus), large-scale stoneroller (Campostoma oligolepis), and striped shiner (Luxilus chrysocephalus), depending on stream size. Generally, males of these host species will create a nest area in the shallow sections where a pool transitions into a riffle or run. The host males fan the nest area or actively move small pebbles to create a zone free of fine sediments. With chubs, only a single male occupies each nest and defends it against other male creek chubs. With stonerollers and striped shiners, the males form a large aggregation and battle for prime spots within the nest area. In both cases, males use these areas to attract females of their species for mating. Tennessee dace are allowed to use these nests as well to form spawning aggregations; apparently the coloration of the male dace, a brilliant red with yellow and gold tints, does not trigger the defensive reaction of the host species. Female dace swim into the nest area, release their eggs which are then fertilized by one or more male dace. The eggs settle into the interstitial spaces between the gravel of the nest. Flowing water, free of silt, provides oxygen to the eggs. Hatching occurs within a few weeks depending on stream temperature.

The breeding season of Tennessee dace can be determined by several methods. Generally, spawning of Tennessee dace has been judged to be very similar to that of other southern Phoxinus species in terms of behavior, nest utilization, and season (Settles and Hoyt 1978). Several researchers have suggested that the spawning season spans the April to July time frame in Tennessee (Starnes and Jenkins 1988; Etnier and Starnes 1993). Unpublished observations by E. M. Schilling and M. G. Ryon indicate that spawning occurs on the ORR from late March (after March 15) through the end of May. Gonad size was examined in dace collected monthly (1989-1990) from Bear Creek and smaller tributaries. The size of the ovaries increased markedly in March and peaked in first week of May. The overall weight declined sharply in June, suggesting an end to spawning. These patterns were also seen in the size and maturity of individual eggs taken during these years, with maximum size occurring the first week of May. Observations of behavior in the field matched this time frame, with active aggregations of male Tennessee dace present in late March through the end of May. These aggregations were seen in Pinhook Branch, lower Bear Creek (just east of Hwy 95), and middle Bear Creek (downstream of NT-7). There is likely some variability in the spawning season depending on variations in flow, water temperature and host spawning activity, which could extend spawning through June if earlier conditions were unfavorable. Larval development proceeds for the two months following the spawn, with larval and juvenile fish occupying shallow, low water velocity areas adjacent to pools. 

APPENDIX C

LIST OF WETLAND PLANTS IDENTIFIED ON APRIL 1, 2005

WITHIN THE HAUL ROAD ROUTE 



\title{
APPENDIX C. \\ LIST OF WETLAND PLANTS IDENTIFIED ON APRIL 1, 2005 WITHIN THE HAUL ROAD ROUTE
}

Species listed by nearest survey marker with common name and wetland classification.

\author{
Survey Marker 359 \\ Cardamine rhomboidea (spring-cress) synonym C. bulbosa OBL \\ Typha latifolia (common cat-tail) OBL \\ Impatiens sp. (jewel-weed) FACW \\ Juncus effusus (soft rush) FACW+ \\ Carex lurida (smaller hop sedge) OBL \\ Ludwigia alternifolia (alternate-leaved seedbox) OBL \\ Galium tinctorium (marsh bedstraw) FACW
}

\author{
Survey Marker 360 \\ Impatiens sp. (jewel-weed) FACW \\ Juncus effusus (soft rush) FACW+ \\ Carex lurida (smaller hop sedge) OBL \\ Selaginella apoda (meadow spikemoss) FACW+ \\ Alisma subcordatum (water-plantain) OBL \\ Erianthus giganteus (tall beardgrass) FACW \\ Helianthus angustifolia (narrow-leaved sunflower) FAC+
}

\section{Survey Marker 364}

Typha latifolia (common cat-tail) OBL

Cardamine rhomboidea (spring-cress) synonym C. bulbosa OBL

Agrimonia parviflora (southern agrimony) FAC

Juncus effusus (soft rush) FACW+

Selaginella apoda (meadow spikemoss) FACW+

\section{Survey Marker 366+50}

Juncus effusus (soft rush) FACW+

Cardamine rhomboidea (spring-cress) synonym C. bulbosa OBL

Alisma subcordatum (water-plantain) OBL

Erianthus giganteus (tall beardgrass) FACW

Scirpus cyperinus (wool-grass) OBL

\section{Survey Marker 389}

Ludwigia alternifolia (alternate-leaved seedbox) OBL

Scirpus pendulus (a bulrush) OBL

Scirpus cyperinus (wool-grass) OBL

Acer rubrum (red maple) FAC

Rubus argutus (highbush blackberry) FACU+

Lonicera japonica (Japanese honeysuckle) FAC- 
Survey Marker 407-415+50

Sambucus canadensis (American elderberry) FACW-

Liquidambar styraciflua (sweetgum) FAC+

Agrimonia parviflora (southern agrimony) FAC

Salix nigra (black willow) OBL

Lindera benzoin (spicebush) FACW

Cardamine rhomboidea (spring-cress) synonym C. bulbosa OBL

Microstegium vimineum (Nepal grass) FAC+ 
ORNL/TM-2005/215

\section{INTERNAL DISTRIBUTION}

1. N. R. Giffen

2. G. K. Jacobs

3. J. M. Loar

4. P. D. Parr

5-30. M. J. Peterson

31. L. R. Pounds
32. E. L. Ryan, Jr.

33. M. G. Ryon

34-36. ESD Library

37. ORNL Central Research Library

38. ORNL Laboratory Records - RC

39. ORNL Laboratory Records - OSTI

\section{EXTERNAL DISTRIBUTION}

40. Bill Barton, Jacobs Engineering, 125 Broadway Avenue, Oak Ridge, TN 37830

41. Tom Conrad, Bechtel Jacobs Corporation, LLC, 1099 Commerce Park, Suite 200, MS 8247, Oak Ridge, TN 37830

42. Jason Darby, Department of Energy, P.O. Box 2001, MS EM-91, Oak Ridge, TN 37831

43. Linda Houlberg, Jacobs Engineering, 125 Broadway Avenue, Oak Ridge, TN 37830

44. Charles Hyer, Jacobs Engineering, 1099 Commerce Park, Suite 200, MS 8247, Oak Ridge, TN 37830

45. Robin Manning, Bechtel Jacobs Corporation, LLC, 1099 Commerce Park, Suite 200, MS 8247, Oak Ridge, TN 37830

46. Bill McMillan, DOE, Department of Energy, P.O. Box 2001, MS EM-91, Oak Ridge, TN 37831

47. Scott Nolter, Streamline Environmental, 518 Echo Valley Road, Knoxville, TN 37923

48. David Page, DOE, Department of Energy, P.O. Box 2001, MS EM-91, Oak Ridge, TN 37831

49. Lynn Sims, Bechtel Jacobs Corporation, LLC, 1099 Commerce Park, Suite 200, MS 8247, Oak Ridge, TN 37830

50. Joe Williams, Bechtel Jacobs Corporation, LLC, 1099 Commerce Park, Suite 200, MS 8247, Oak Ridge, TN 37830 